\title{
SLUDGE BATCH 4 (SB4): MODEL BASED ASSESSMENTS OF THE FEBRUARY 2007 SLUDGE PROJECTION
}

D.K. Peeler

T.B. Edwards

K.M. Fox

February 2007

Process Science and Engineering Section Savannah River National Laboratory

Aiken, SC 29808 
WSRC-STI-2007-00088

Revision 0

\section{DISCLAIMER}

This report was prepared by Washington Savannah River Company (WSRC) for the United States Department of Energy under Contract No. DE-AC09-96SR18500 and is an account of work performed under that contract. Neither the United States Department of Energy, nor WSRC, nor any of their employees makes any warranty, expressed or implied, or assumes any legal liability or responsibility for the accuracy, completeness, or usefulness, of any information, apparatus, or product or process disclosed herein or represents that its use will not infringe privately owned rights. Reference herein to any specific commercial product, process, or service by trademark, name, manufacturer or otherwise does not necessarily constitute or imply endorsement, recommendation, or favoring of same by WSRC or by the United States Government or any agency thereof. The views and opinions of the authors expressed herein do not necessarily state or reflect those of the United States Government or any agency thereof.

\section{Printed in the United States of America \\ Prepared For U.S. Department of Energy}

The Savannah River National Laboratory is operated for the U.S. Department of Energy by Washington Savannah River Company. 
Key Words: durability, model predictions, operating windows

Retention: Permanent

\section{SLUDGE BATCH 4 (SB4): MODEL BASED ASSESSMENTS OF THE FEBRUARY 2007 SLUDGE PROJECTION}

D.K. Peeler

T.B. Edwards

K.M. Fox

February 2007

Process Science and Engineering Section Savannah River National Laboratory Aiken, SC 29808 
WSRC-STI-2007-00088

Revision 0

\section{REVIEWS AND APPROVALS}

\section{AUTHORS:}

D.K. Peeler, Process Science and Engineering Section

Date

T.B. Edwards, Statistical Consulting Section

Date

K.M. Fox, Material Science and Technology Section

Date

\section{TECHNICAL REVIEWER:}

M.E. Stone, Process Science and Engineering Section

Date

\section{APPROVERS:}

C.C. Herman, Manager, Process Engineering Technology Group

Date

R.E. Edwards, Manager, Process Science and Engineering Section

Date

J.E. Occhipinti, Manager,

Date

Process Cognizant Engineer - Waste Solidification Engineering 
WSRC-STI-2007-00088

Revision 0

\section{EXECUTIVE SUMMARY}

The Savannah River National Laboratory (SRNL) has developed, and continues to enhance, its integrated capability to evaluate the impact of proposed sludge preparation plans on the Defense Waste Processing Facility's (DWPF's) operation. One of the components of this integrated capability focuses on frit development which identifies a viable frit or frits for each sludge option being contemplated for DWPF processing. A frit is considered viable if its composition allows for economic fabrication and if, when it is combined with the sludge option under consideration, the DWPF property/composition models (the models of DWPF's Product Composition Control System (PCCS)) indicate that the combination has the potential for an operating window (a waste loading (WL) interval over which the sludge/frit glass system satisfies processability and durability constraints) that would allow DWPF to meet its goals for waste loading and canister production.

This report documents the results of SRNL's efforts to identify candidate frit compositions and corresponding predicted operating windows (defined in terms of WL intervals) for the February 2007 compositional projection of Sludge Batch 4 (SB4) developed by the Liquid Waste Organization (LWO). The nominal compositional projection was used to assess projected operating windows (in terms of a waste loading interval over which all predicted properties were classified as acceptable) for various frits, evaluate the applicability of the $0.6 \mathrm{wt} \% \mathrm{SO}_{4}{ }^{=}$PCCS limit to the glass systems of interest, and determine the impact (or lack thereof) to the previous SB4 variability studies. It should be mentioned that the information from this report will be coupled with assessments of melt rate to recommend a frit for SB4 processing.

The results of this paper study suggest that candidate frits are available to process the nominal SB4 composition over attractive waste loadings of interest to DWPF. Specifically, two primary candidate frits for SB4 processing, Frit 510 and Frit 418, have projected operating windows that should allow for successful processing at DWPF. While Frit 418 has been utilized at DWPF, Frit 510 is a higher $\mathrm{B}_{2} \mathrm{O}_{3}$ based frit which could lead to improvements in melt rate. These frits provide relatively large operating windows and demonstrate robustness to possible sludge compositional variation while avoiding potential nepheline formation issues. In addition, assessments of $\mathrm{SO}_{4}{ }^{=}$solubility indicate that the $0.6 \mathrm{wt} \% \mathrm{SO}_{4}{ }^{=}$limit in PCCS is applicable for the Frit 418 and the Frit 510 based SB4 glass systems. 


\section{TABLE OF CONTENTS}

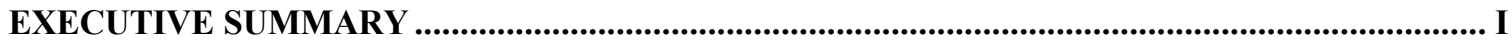

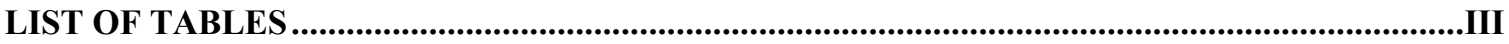

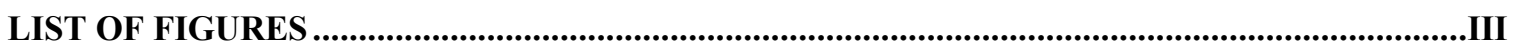

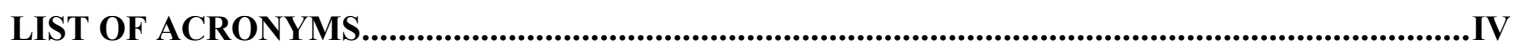

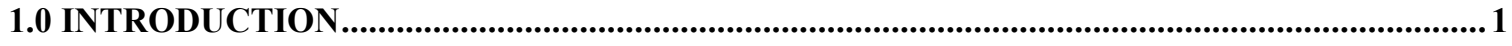

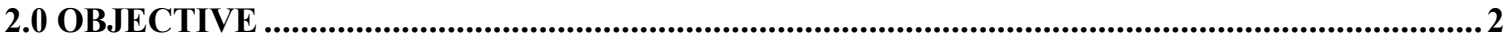

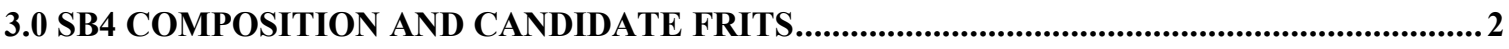

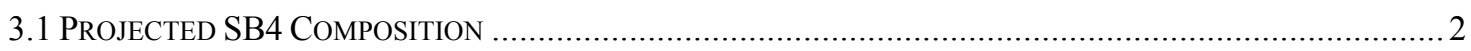

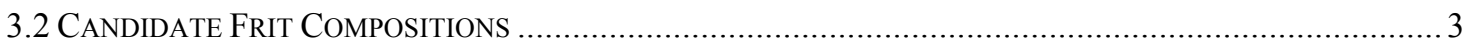

4.0 THE APPROACH AND CRITERIA FOR ACCEPTABILITY ..................................................6

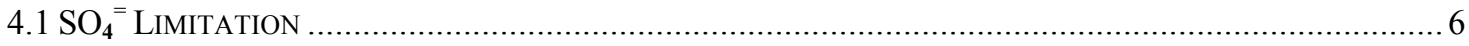

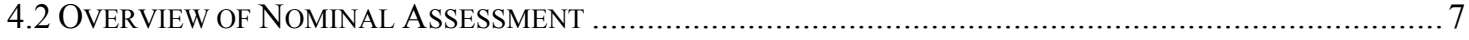

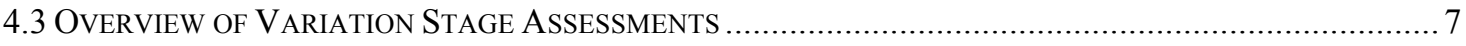

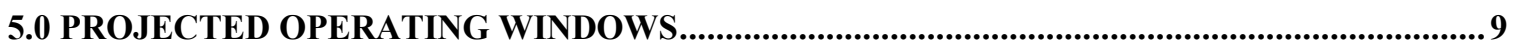

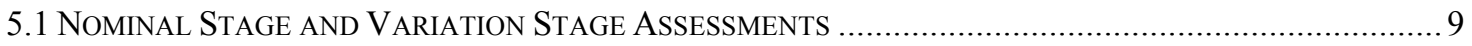

5.2 IMPACT OF $\mathrm{SO}_{4}{ }^{=}$

6.0 IMPACT TO SB4 VARIABILITY STUDY …...........................................................................15

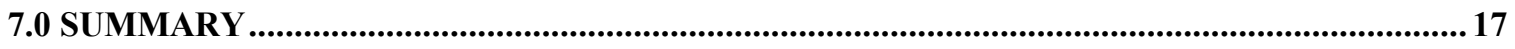

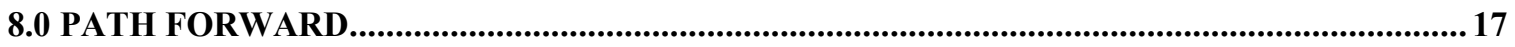

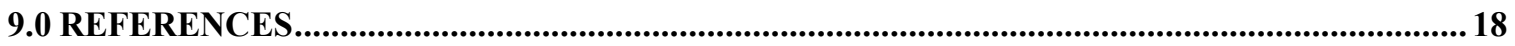

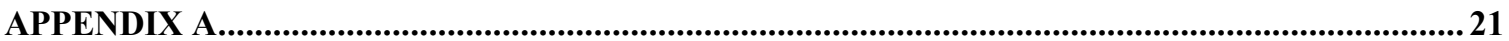




\section{LIST OF TABLES}

TABLE 3-1. NOMINAL SB4 PROJECTED COMPOSITIONS (WT\% CALCINED BASIS)................... 3

TABLE 3-2. NOMINAL COMPOSITIONS (IN WT\%) OF CANDIDATE FRITS ….............................. 5

TABLE 4-1. VARIATION STAGE BOUNDING REGION FOR SB4 FEBRUARY 2007 SLUDGE

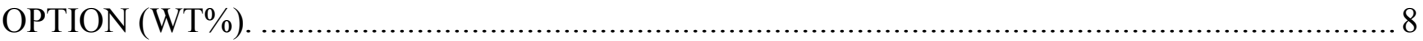

TABLE 4-2. COMPONENTS (WT\%) OF “OTHERS” FOR THE SB4 FEBRUARY 2007 OPTION. ....... 8

TABLE 5-1. NOMINAL AND VARIATION STAGE ASSESSMENT RESULTS FOR THE $8 \% \mathrm{~B}_{2} \mathrm{O}_{3}$ BASED FRITS.

TABLE 5-2. NOMINAL AND VARIATION STAGE ASSESSMENT RESULTS FOR THE $14 \% \mathrm{~B}_{2} \mathrm{O}_{3}$ BASED FRITS.

TABLE 5-3. PREDICTED $\mathrm{SO}_{4}{ }^{-}$SOLUBILITY LIMITS FOR VARIOUS JUNE 2006 SB4 SYSTEMS. 14

TABLE 5-4. PREDICTED $\mathrm{SO}_{4}{ }^{=}$SOLUBILITY LIMITS USING THE FEBRUARY 2007 SB4 COMPOSITION

\section{LIST OF FIGURES}

FIGURE 5-1. PRELIMINARY MRF RESULTS USING THE JUNE 2006 SB4 PROJECTIONS. 10

FIGURE 6-1. HISTORICAL GLASSES WITH THE FRIT 510 - SB4 AND FRIT 418 SB4COMPOSITIONAL REGIONS OF INTEREST. 


\section{LIST OF ACRONYMS}

$\begin{array}{ll}\text { ARP } & \text { Actinide Removal Process } \\ \text { CPC } & \text { Chemical Process Cell } \\ \text { DWPF } & \text { Defense Waste Processing Facility } \\ \text { EV } & \text { Extreme Vertices } \\ \Delta G_{P} & \text { preliminary glass dissolution estimator } \\ \text { LWO } & \text { Liquid Waste Organization } \\ \text { MAR } & \text { Measurement Acceptability Region } \\ \text { MCU } & \text { Modular Caustic Side Solvent Extraction Unit } \\ \text { MRF } & \text { Melt Rate Furnace } \\ \text { PCCS } & \text { Product Composition Control System } \\ \text { PCT } & \text { Product Consistency Test } \\ \text { SB } & \text { sludge batch } \\ \text { SME } & \text { Slurry Mix Evaporator } \\ \text { SMRF } & \text { Slurry-Fed Melt Rate Furnace } \\ \text { SRNL } & \text { Savannah River National Laboratory } \\ T_{L} & \text { liquidus temperature } \\ \eta & \text { viscosity } \\ \text { WL } & \text { waste loading } \\ \text { wt } \% & \text { weight percent }\end{array}$




\subsection{INTRODUCTION}

The Savannah River National Laboratory (SRNL) has been supporting the development of the preparation plan for the next sludge batch (i.e., Sludge Batch 4, SB4) for the Defense Waste Processing Facility (DWPF) by the Liquid Waste Organization (LWO). The components of this support include frit development, Chemical Process Cell (CPC) flowsheet development, and studies of melt rate. The completion of these efforts and the integration of their results are to drive one of SRNL's primary deliverables in support of the LWO planning: a frit recommendation for SB4. To support the frit recommendation, Shah (2007) provided a nominal SB4 composition that has been revised to reflect the extended processing of SB3 and the decant of Tank 40 to adjust the rheological properties of SB4 for transfer. ${ }^{1}$ The revised SB4 composition will be referred to throughout this report as the February 2007 projection. As defined by the blending strategy, SB4 will consist of approximately $30 \%$ of Tank 51 (mainly Tank 11) insoluble solids that will be transferred to Tank 40, which will contribute approximately $70 \%$ of the insoluble solids. This report provides an assessment of projected DWPF operating windows (defined in terms of waste loadings (WL)) for this SB4 composition with select frits. In addition, assessments of the $\mathrm{SO}_{4}{ }^{=}$solubility and the need for a supplemental variability study are made. It is noted that no experimental work was performed as part of this study. Although not documented in this report, experimental assessments of melt rate are being made and will ultimately be used as part of the technical basis from which a frit recommendation for SB4 will be based.

The projected operating windows presented as part of this analysis are based on the same models that are employed by DWPF's Product Composition Control System (PCCS). The assessment may be described as a paper study that identifies a viable frit or frits for each sludge option being contemplated. A frit is considered viable if its composition allows for economic fabrication and if, when it is combined with a sludge option under consideration, the DWPF property/composition models indicate that the combination has an operating window (a WL interval over which the sludge/frit glass system satisfies processability and durability constraints) that allows DWPF to meet its goals for waste loading and canister production.

From a processing perspective, having candidate frits available that provide relatively large operating windows and that are robust to sludge variation is critical to DWPF operations. SRNL was asked to provide frit development support via a technical task request (Washburn 2004), and SRNL responded to the request by issuing a task technical and quality assurance plan (Peeler 2004) under whose auspices the previous frit studies and this current report were prepared. The assessments presented here are strictly paper studies driven by predictions from glass property/glass composition models, which are currently used by DWPF to control its process and the quality (i.e., the durability) of its final product - no experimental work was conducted to support the assessments documented in this report.

Objectives of the frit development task are specified in Section 2.0. The nominal February 2007 composition is provided in Section 3.0. Also discussed in Section 3.0 are the candidate frits and the strategy behind their use. Section 4.0 provides a brief overview of how sludge/frit glass systems

\footnotetext{
${ }^{1}$ It should be noted that Frit 503 was recommended for SB4 processing based on a June 2006 composition. Since that time, rheological issues associated with Tank 51 have resulted in the need to decant Tank 40 into Tank 51 to adjust the rheological properties. In addition, LWO has decided to extend processing of SB3, which will lower the mass of SB3 to be blended with SB4. The most dramatic impact of this flowsheet change was a significant reduction in the $\mathrm{Na}_{2} \mathrm{O}$ content of SB4. As will be shown, the lower $\mathrm{Na}_{2} \mathrm{O}$ content of $\mathrm{SB} 4$ coupled with the low $\mathrm{Na}_{2} \mathrm{O}$ content of Frit 503 results in relatively small operating window for SB4 - hence the need to provide a second frit recommendation for SB4.
} 
were assessed for this study. Two stages were performed in the assessment: a Nominal Stage (a screening tool applied to a large set of candidate frits) and a Variation Stage (a more thorough assessment applied to select sludge/frit systems). Both assessments used the same criteria to make acceptability decisions that led to a projected operating window (an interval of waste loading over which all the criteria were simultaneously satisfied) that may be achieved for a specific sludge/frit glass system. Section 5.0 provides the results of the Nominal Stage and Variation Stage assessments and a discussion of how an imposed $\mathrm{SO}_{4}{ }{ }^{2}$ solubility limit may influence acceptable WL intervals or the projected operating window. Section 6.0 evaluates the impact to the SB4 variability study. Section 7.0 and Section 8.0 provide a summary of these assessments and a recommended path forward, respectively.

\subsection{OBJECTIVE}

The objective of this report is to document the results of SRNL's efforts to identify candidate frit compositions and corresponding predicted operating windows for the February 2007 nominal SB4 composition. Of primary interest will be the identification of a candidate frit(s) for the projected SB4 composition that:

(1) provides, for the nominal composition, a relatively large operating window (from a PCCS Slurry Mix Evaporator (SME) acceptability perspective) that covers a WL interval that allows DWPF to meet its processing goals, and

(2) demonstrates a relatively high degree of robustness to the compositional variation anticipated in the sludge.

Although these are the primary goals of interest, additional information will be presented and discussed as warranted. In particular, an assessment will be provided of the effectiveness of the "sliding $\mathrm{Na}_{2} \mathrm{O}$ scale" frits to accommodate compositional changes and/or the ability of the specifically designed "strategic" frits (higher $\mathrm{B}_{2} \mathrm{O}_{3}$ frits) to minimize the potential negative impacts of nepheline formation on the projected operating windows or to improve melt rate for high $\mathrm{Al}_{2} \mathrm{O}_{3}$ feeds. As previously mentioned, the results presented in this report are solely based on model predictions and do not include any experimental work (such as melt rate assessments). ${ }^{2}$

\subsection{SB4 COMPOSITION AND CANDIDATE FRITS}

In this section, the projected SB4 composition under consideration by the LWO is provided. ${ }^{3}$ In addition, an extensive set of frits that was used for these assessments is also presented and discussed.

\subsection{Projected SB4 Composition}

Table 3-1 summarizes the projected February 2007 sludge composition that was considered in this study as well as the June 2006 projected compositions for SB4. Elemental concentrations for these options were provided to the frit development team, and these were converted to oxide concentrations by multiplying the values for each element by the gravimetric factor for the corresponding oxide. The compositions submitted to the frit development team did not include estimates of the $\mathrm{SO}_{4}{ }^{=}$ concentrations. However, LWO personnel did provide information, as part of the washing scenarios

\footnotetext{
${ }^{2}$ Smith et al. (2006) discusses the melt rate assessments for June 2006 SB4 projection associated with the Frit 418, Frit 425, and Frit 503.

${ }^{3}$ H.B. Shah provided the nominal SB4 projected composition via email communications on February 5, 2007 (see WSRCNB-2006-00017, pages 122 - 123 for more details). Subsequently, Shah (2007) issued LWO-PIT-2007-00017, Revision 0 (Estimate of Sludge Batch 4 and 5 Calcine Composition for SRNL) documenting these projections.
} 
and preparations plans, that was used to derive estimates for the $\mathrm{SO}_{4}{ }^{=}$concentrations. The projected $\mathrm{SO}_{4}{ }^{=}$concentration was added to the oxide list and the resulting oxide concentrations were then normalized to $100 \%$. It should be noted that the projected sludge compositions presented in Table 3-1 are sludge-only flowsheets and do not account for any potential secondary streams from the Actinide Removal Process (ARP) or the Modular Caustic Side Solvent Extraction Unit (MCU).

As seen in Table 3-1, the projected sludge composition is relatively high in $\mathrm{Al}_{2} \mathrm{O}_{3}, \mathrm{Na}_{2} \mathrm{O}$, and $\mathrm{SO}_{4}{ }^{=}$ and relatively low in $\mathrm{Fe}_{2} \mathrm{O}_{3}$ (as compared to previous sludges processed in DWPF). Also shown in Table 3-1 are the two SB4 options from June 2006 prior to the decision to decant Tank 40 to adjust the rheological properties of Tank 51 and prior to adjustment of the projected composition through the use of updated composition information. The most notable compositional change is in the $\mathrm{Na}_{2} \mathrm{O}$ concentration which dropped from $\sim 23.5 \mathrm{wt} \%$ in June 2006 to $\sim 17.5 \mathrm{wt} \%$ for the February 2007 projections. This reduction will lead to questions regarding the potential use of Frit 503 (as recommended by Peeler et al. (2006a) based on the June 2006 composition).

Table 3-1. Nominal SB4 Projected Compositions (wt\% calcined basis).

\begin{tabular}{||c|c|c|c||}
\hline & February 2007 & \multicolumn{2}{|c||}{ June 2006 } \\
\hline & SB4 Blend & $\begin{array}{c}\mathbf{1 2 . 2} \text { wt\%, } \\
\mathbf{0 . 9 2} \mathbf{~ M ~ N a}\end{array}$ & $\begin{array}{c}\mathbf{1 2 . 6} \text { wt\%, } \\
\mathbf{0 . 9 1 2} \mathbf{~ M}\end{array}$ \\
\hline $\mathbf{A l}_{2} \mathbf{O}_{3}$ & $\mathbf{2 4 . 8 3}$ & $\mathbf{2 3 . 7 5 0}$ & $\mathbf{2 3 . 9 6 5}$ \\
\hline $\mathrm{BaO}$ & 0.07 & 0.124 & 0.125 \\
\hline $\mathrm{CaO}$ & 2.86 & 2.350 & 2.371 \\
\hline $\mathrm{Ce}_{2} \mathrm{O}_{3}$ & 0.22 & 0.150 & 0.151 \\
\hline $\mathrm{Cr}_{2} \mathrm{O}_{3}$ & 0.20 & 0.208 & 0.210 \\
\hline $\mathrm{CuO}$ & 0.05 & 0.060 & 0.060 \\
\hline $\mathrm{Fe}_{2} \mathrm{O}_{3}$ & 29.93 & 26.165 & 26.401 \\
\hline $\mathrm{K}_{2} \mathrm{O}$ & 0.06 & 0.329 & 0.332 \\
\hline $\mathrm{MgO}$ & 2.89 & 2.480 & 2.502 \\
\hline $\mathrm{MnO}$ & 5.95 & 5.394 & 5.442 \\
\hline $\mathbf{N a}_{2} \mathbf{O}$ & $\mathbf{1 7 . 5 2}$ & $\mathbf{2 3 . 8 8 7}$ & $\mathbf{2 3 . 2 6 1}$ \\
\hline $\mathrm{NiO}$ & 1.70 & 1.545 & 1.559 \\
\hline $\mathrm{PbO}$ & 0.19 & 0.091 & 0.091 \\
\hline $\mathbf{S O}_{\mathbf{4}}$ & $\mathbf{1 . 0 9}$ & $\mathbf{1 . 4 1 7}$ & $\mathbf{1 . 3 6 8}$ \\
\hline $\mathrm{SiO}_{2}$ & 2.80 & 3.963 & 3.998 \\
\hline $\mathrm{ThO}_{2}$ & 0.03 & 0.063 & 0.063 \\
\hline $\mathrm{TiO}_{2}$ & 0.03 & 0.026 & 0.026 \\
\hline $\mathrm{U}_{3} \mathrm{O}_{8}$ & 9.38 & 7.563 & 7.632 \\
\hline $\mathrm{ZrO}_{2}$ & 0.09 & 0.232 & 0.235 \\
\hline \hline & & & \\
\hline
\end{tabular}

\subsection{Candidate Frit Compositions}

Table 3-2 provides the list of candidate frits and their nominal compositions (on a $\mathrm{wt} \%$ basis) that were considered in this assessment. A closer review of Frits X1-1 through 422 (shaded in Table 3-2) indicates fixed concentrations of $\mathrm{B}_{2} \mathrm{O}_{3}$ and $\mathrm{Li}_{2} \mathrm{O}$ at $8 \mathrm{wt} \%$ with only the $\mathrm{Na}_{2} \mathrm{O}$ and $\mathrm{SiO}_{2}$ concentrations varying. In general, these frit compositions decrease in $\mathrm{Na}_{2} \mathrm{O}$ by $1 \%$ and increase correspondingly in $\mathrm{SiO}_{2}$, proceeding from Frit X1-1 to Frit 422. This system has been referred to as a 
"sliding $\mathrm{Na}_{2} \mathrm{O}$ scale" concept, which was developed to accommodate potential sludge $\mathrm{Na}_{2} \mathrm{O}$ concentration differences as a result of various washing strategies considered for Sludge Batch 3 (SB3) (see Peeler and Edwards (2002) for more details).

Frits 202 and 200 are historical frits that were developed to support both the coupled and sludge-only flowsheets. They are being carried forward in this assessment to provide insight into their potential use with the latest SB4 compositional projection shown in Table 3-1. The "P-series", T1-1, "418-m" series, and the " $200-\mathrm{m}$ " series of frits have been developed to minimize the potential for nepheline formation given its impact on durability (Peeler et al. (2005 and 2006b) and Fox et al. (2006a and 2006b)). In general, these frits have lower $\mathrm{Na}_{2} \mathrm{O}$ concentrations than the "sliding scale series" with the differences being accounted for by increases in $\mathrm{Li}_{2} \mathrm{O}, \mathrm{B}_{2} \mathrm{O}_{3}$, and/or $\mathrm{Fe}_{2} \mathrm{O}_{3}$ (individually or in combination). The intent in introducing this series of frits was to find combinations of $\mathrm{Na}_{2} \mathrm{O}$ and $\mathrm{SiO}_{2}$ concentrations that suppressed the potential for nepheline formation to higher WLs with the adjustments in $\mathrm{Li}_{2} \mathrm{O}, \mathrm{B}_{2} \mathrm{O}_{3}$, and/or $\mathrm{Fe}_{2} \mathrm{O}_{3}$ hopefully maintaining (or regaining) melt rate, which would presumably be lower given the lower $\mathrm{Na}_{2} \mathrm{O}$ concentrations.

Perhaps of most interest to SB4 is the Frit 503-m series (also shaded in Table 3-2). This series of frits was developed during the November 2006 SB4 assessments based on the preliminary melt rate information that suggested higher $\mathrm{B}_{2} \mathrm{O}_{3}$ based frits could lead to higher melt rates (Smith et al. (2006)). ${ }^{4}$ That being said, the 503-m series is primarily based on a fixed $\mathrm{B}_{2} \mathrm{O}_{3}$ content of $14 \%$ with varying $\mathrm{Na}_{2} \mathrm{O}$ concentrations (ranging from $4-10 \mathrm{wt} \%$ ) so the frit selection process can couple to the washing endpoint of the sludge, which plays a major role in determining the sludge $\mathrm{Na}_{2} \mathrm{O}$ content. As previously mentioned, Frit 503 (with $4 \% \mathrm{Na}_{2} \mathrm{O}$ ) was recommended for SB4 processing based on the June 2006 composition. This frit has been shown to improve melt rate over Frit 418, 425, and 320 , even though the $\mathrm{Na}_{2} \mathrm{O}$ content is significantly lower (Smith et al. (2006)).

There are 69 frits in Table 3-2, and all of these frits were coupled with the nominal February 2007 SB4 composition (see Table 3-1) during the Nominal Stage assessment. If a frit, when combined with the sludge option, was found during the Nominal Stage assessment to have an attractive operating window, it was a prime candidate for further consideration during the Variation Stage assessments for that sludge option. In the latter statement, an attractive operating window is defined as one that was not restricted by the potential for nepheline formation or "pushed" the predicted nepheline formation to relatively high WLs.

\footnotetext{
${ }^{4}$ Preliminary assessments of the November 2006 SB4 projections can be found in WSRC-NB-2006-00017, pp. 98 - 104.
} 
Table 3-2. Nominal Compositions (in wt\%) of Candidate Frits

\begin{tabular}{|c|c|c|c|c|c|c|}
\hline \multirow{2}{*}{ Frit } & \multicolumn{6}{|c|}{ Oxide Composition } \\
\hline & $\mathbf{B}_{2} \mathbf{O}_{3}$ & $\mathrm{Fe}_{2} \mathrm{O}_{3}$ & $\mathbf{L i}_{2} \mathbf{O}$ & $\mathrm{MgO}$ & $\mathrm{Na}_{2} \mathrm{O}$ & $\mathrm{SiO}_{2}$ \\
\hline $\mathrm{X} 1-1$ & 8 & 0 & 8 & 0 & 15 & 69 \\
\hline Y1-1 & 8 & 0 & 8 & 0 & 14 & 70 \\
\hline 431 & 8 & 0 & 8 & 0 & 13 & 71 \\
\hline 320 & 8 & 0 & 8 & 0 & 12 & 72 \\
\hline 417 & 8 & 0 & 8 & 0 & 11 & 73 \\
\hline 425 & 8 & 0 & 8 & 0 & 10 & 74 \\
\hline 426 & 8 & 0 & 8 & 0 & 9 & 75 \\
\hline 418 & 8 & 0 & 8 & 0 & 8 & 76 \\
\hline 460 & 8 & 0 & 8 & 0 & 7 & 77 \\
\hline 432 & 8 & 0 & 8 & 0 & 6 & 78 \\
\hline 473 & 8 & 0 & 8 & 0 & 5 & 79 \\
\hline D1-1 & 8 & 0 & 8 & 0 & 4 & 80 \\
\hline 422 & 8 & 0 & 8 & 0 & 3 & 81 \\
\hline 202 & 8 & 0 & 7 & 2 & 6 & 77 \\
\hline 200 & 12 & 0 & 5 & 2 & 11 & 70 \\
\hline P1-1 & 8 & 4 & 8 & 0 & 5 & 75 \\
\hline P2-1 & 8 & 4 & 10 & 0 & 5 & 73 \\
\hline P2-2 & 8 & 5 & 11 & 0 & 5 & 71 \\
\hline P2-3 & 8 & 3 & 10 & 0 & 6 & 73 \\
\hline P2-4 & 8 & 5 & 11 & 0 & 6 & 70 \\
\hline P2-5 & 8 & 5 & 10 & 0 & 7 & 70 \\
\hline P3-1 (502) & 8 & 0 & 11 & 0 & 5 & 76 \\
\hline P3-2 & 8 & 1 & 10 & 0 & 6 & 75 \\
\hline P3-3 & 8 & 1 & 10 & 0 & 7 & 74 \\
\hline P3-4 & 8 & 0 & 10 & 0 & 7 & 75 \\
\hline T1-1 & 8 & 2 & 8 & 0 & 5 & 77 \\
\hline 418-m1 (501) & 9 & 0 & 10 & 0 & 5 & 76 \\
\hline $418-\mathrm{m} 2$ & 8 & 3 & 8 & 0 & 5 & 76 \\
\hline 418-m3 & 9 & 1 & 9 & 0 & 5 & 76 \\
\hline $418-\mathrm{m} 4$ & 9 & 2 & 8 & 0 & 5 & 76 \\
\hline $200-\mathrm{m} 1$ & 10 & 0 & 9 & 0 & 5 & 76 \\
\hline $200-\mathrm{m} 2$ & 12 & 0 & 9 & 0 & 5 & 74 \\
\hline $418-\mathrm{m} 5$ & 11 & 0 & 8 & 0 & 5 & 76 \\
\hline 418-m6 & 8 & 3 & 8 & 0 & 5 & 76 \\
\hline 418-m7 & 10 & 1 & 9 & 0 & 5 & 75 \\
\hline 418-m8 & 11 & 1 & 9 & 0 & 4 & 75 \\
\hline 418-m9 & 12 & 1 & 9 & 0 & 4 & 74 \\
\hline
\end{tabular}

\begin{tabular}{|c|c|c|c|c|c|c|}
\hline \multirow{2}{*}{ Frit } & \multicolumn{6}{|c|}{ Oxide Composition } \\
\hline & $\mathbf{B}_{2} \mathbf{O}_{3}$ & $\mathrm{Fe}_{2} \mathrm{O}_{3}$ & $\mathbf{L i}_{2} \mathbf{O}$ & MgO & $\mathrm{Na}_{2} \mathrm{O}$ & $\mathrm{SiO}_{2}$ \\
\hline $418-\mathrm{m} 11$ & 12 & 0 & 8 & 0 & 4 & 76 \\
\hline 418-m12 & 16 & 0 & 8 & 0 & 4 & 72 \\
\hline 418-m13 & 18 & 0 & 8 & 0 & 4 & 70 \\
\hline 418-m14/504 & 20 & 0 & 8 & 0 & 4 & 68 \\
\hline $418-\mathrm{m} 15$ & 13 & 0 & 8 & 0 & 5 & 74 \\
\hline $418-\mathrm{m} 16$ & 12 & 0 & 8 & 0 & 5 & 75 \\
\hline 418-m17 & 16 & 0 & 8 & 0 & 5 & 71 \\
\hline $418-\mathrm{m} 18$ & 18 & 0 & 8 & 0 & 5 & 69 \\
\hline $418-\mathrm{m} 19$ & 20 & 0 & 8 & 0 & 5 & 67 \\
\hline 418-m21 & 16 & 0 & 8 & 0 & 6 & 70 \\
\hline 418-m22 & 18 & 0 & 8 & 0 & 6 & 68 \\
\hline 418-m23/506 & 14 & 4 & 8 & 0 & 6 & 68 \\
\hline $418-\mathrm{m} 24$ & 14 & 4 & 8 & 0 & 4 & 70 \\
\hline $418-\mathrm{m} 25$ & 14 & 6 & 8 & 0 & 4 & 68 \\
\hline 418-m26 & 14 & 8 & 8 & 0 & 4 & 66 \\
\hline $418-\mathrm{m} 28 / 507$ & 14 & 4 & 10 & 0 & 4 & 68 \\
\hline $418-\mathrm{m} 29$ & 14 & 6 & 10 & 0 & 4 & 66 \\
\hline $418-\mathrm{m} 30$ & 14 & 8 & 10 & 0 & 4 & 64 \\
\hline $418-\mathrm{m} 31$ & 14 & 4 & 9 & 0 & 5 & 68 \\
\hline $418-\mathrm{m} 32$ & 14 & 5 & 9 & 0 & 4 & 68 \\
\hline $418-\mathrm{m} 10(503)$ & 14 & 0 & 8 & 0 & 4 & 74 \\
\hline $503-\mathrm{m} 1 / 508$ & 14 & 0 & 8 & 0 & 5 & 73 \\
\hline $418-\mathrm{m} 20 / 505$ & 14 & 0 & 8 & 0 & 6 & 72 \\
\hline $503-\mathrm{m} 2 / 509$ & 14 & 0 & 8 & 0 & 7 & 71 \\
\hline $503-\mathrm{m} 3 / 510$ & 14 & 0 & 8 & 0 & 8 & 70 \\
\hline $503-\mathrm{m} 4 / 511$ & 14 & 0 & 8 & 0 & 9 & 69 \\
\hline 503-m5/512 & 14 & 0 & 8 & 0 & 10 & 68 \\
\hline 503-m6 & 16 & 0 & 8 & 0 & 8 & 68 \\
\hline $503-\mathrm{m} 7$ & 16 & 0 & 8 & 0 & 10 & 66 \\
\hline $503-\mathrm{m} 8$ & 14 & 0 & 7 & 0 & 6 & 73 \\
\hline 503-m9 & 14 & 0 & 6 & 0 & 8 & 72 \\
\hline 503-m10 & 14 & 0 & 5 & 0 & 10 & 71 \\
\hline
\end{tabular}




\subsection{THE APPROACH AND CRITERIA FOR ACCEPTABILITY}

As stated in Section 2.0, the assessments conducted as part of this effort were strictly paper studies that were driven by predictions from glass property/glass composition models. However, the assessments do provide meaningful insight into the viability of sludge/frit glass systems since the models used in the assessments are the same as the models anticipated to be in DWPF's PCCS during the processing of SB4. The major property models included those for liquidus temperature $\left(T_{L}\right)$, viscosity $(\eta)$, and durability (as defined by the Product Consistency Test [PCT] [ASTM 2002] response in terms of the preliminary glass dissolution estimator $\left(\Delta \mathrm{G}_{\mathrm{P}}\right)$ (Jantzen et al. 1995)). It should be noted that the new durability limits by Edwards et al. (2003) and the new viscosity model developed by Jantzen (2005) were used in this assessment. Jantzen et al. (1995), Brown et al. (2001), and Brown, Postles, and Edwards (2006) provide a more detailed discussion on the development of the PCCS models. In addition, the potential for the formation of a nepheline primary crystalline phase was also included in the assessment using a nepheline discriminator function as described by Li et al. (2003). ${ }^{5}$ Based on recent experimental results (Peeler et al. (2005 and 2006b) and Fox et al. (2006a and 2006b)), a strategy for controlling or limiting access to WLs at which nepheline formation can lead to detrimental effects on durability was recommended. In response to this need, Edwards et al. (2006) provided the technical basis for implementing the nepheline discriminator into PCCS for SB4 processing.

There are two stages of investigation that have been developed and employed by the frit development team in the assessment of frits for a candidate sludge: a Nominal Stage (a screening tool for the sludge that is typically applied to a large set of candidate frits such as that provided in Table 3-2) and a Variation Stage (a more thorough assessment of the sludge conducted for a select set of frits). These are discussed in Sections 4.2 and 4.3, respectively. For both stages, glass compositions were generated to represent combinations of the sludge and frit at waste loadings of interest. The acceptability of the model predictions for a particular glass composition for either stage was judged by employing the same criteria that are used by PCCS in its Measurement Acceptability Region (MAR) evaluations. Acceptable predicted properties for this assessment were based on satisfying their respective MAR limits. Brown, Postles, and Edwards (2006) provide a detailed discussion of how the MAR limits are utilized for SME acceptability decisions in PCCS. Thus, the value of the frit development effort in its assessment of a glass composition is that it mirrors the results that would be generated by the PCCS MAR criteria for the same glass.

\section{1 $\mathrm{SO}_{4}{ }^{=}$Limitation}

In the MAR assessments of the sludge compositions that follow (both Nominal and Variation Stages), the $\mathrm{SO}_{4}{ }^{=}$concentrations in the glass were calculated, but an assumed $\mathrm{SO}_{4}{ }^{=}$limit was not used to restrict the projected operating windows. Given there is no MAR uncertainty associated with the $\mathrm{SO}_{4}{ }^{=}$concentration, the maximum WL for a sludge projection can be determined as a function of an assumed $\mathrm{SO}_{4}{ }^{-}$solubility limit based strictly on mathematics (i.e., the assumed $\mathrm{SO}_{4}{ }^{=}$ solubility limit divided by the $\mathrm{SO}_{4}{ }^{=}$concentration in sludge multiplied by 100). Although one can easily calculate the maximum WL for a given $\mathrm{SO}_{4}{ }^{2}$ solubility limit (assuming no volatility), properties other than $\mathrm{SO}_{4}{ }^{=}$solubility may restrict the upper WL prior to the assumed $\mathrm{SO}_{4}{ }^{\prime}$ limit.

\footnotetext{
${ }^{5} \mathrm{Li}$ et al. (2003) indicate that sodium alumino-borosilicate glasses are prone to nepheline crystallization if their compositions projected on the $\mathrm{Na}_{2} \mathrm{O}-\mathrm{Al}_{2} \mathrm{O}_{3}-\mathrm{SiO}_{2}$ ternary fall within the nepheline primary phase field. In particular, durable glasses with $\mathrm{SiO}_{2} /\left(\mathrm{SiO}_{2}+\mathrm{Na}_{2} \mathrm{O}+\mathrm{Al}_{2} \mathrm{O}_{3}\right)>0.62$, where the oxides are expressed as mass fractions in the glass, do not precipitate nepheline as their primary phase. It should be noted that higher $\mathrm{B}_{2} \mathrm{O}_{3}$ concentrations in glass suppress nepheline formation and therefore the current 0.62 value may be conservative for certain glass forming regions.
} 
An assessment of the $\mathrm{SO}_{4}{ }^{=}$limit and its potential impact on the upper WL attainable for select options are provided in Section 5.2.

\subsection{Overview of Nominal Stage Assessment}

In general, the Nominal Stage evaluation provides a quick assessment of the viability of a particular sludge option relative to a potentially large set of candidate frits. The Nominal Stage assessment was conducted for the nominal SB4 February 2007 composition. Only the nominal composition of the sludge was used in this stage of the evaluation - no sludge variation was taken into account. Glass compositions were generated for a sludge/frit system at waste loadings of 25 to $60 \%$ in increments of 1 percentage point. This lead to the generation of 36 glass compositions for each sludge/frit combination. Each of these glasses was evaluated against the PCCS MAR criteria and its acceptability was determined. The resulting evaluation identified a sub-interval within the 25 to $60 \%$ interval of WLs that defined the projected operating window in WL-space for the SB4/frit glass system. The evaluation also identified the property model (e.g., $\eta$ or $\mathrm{T}_{\mathrm{L}}$ ) that limited the operating window when the window was restricted at either or both ends of the 25 to $60 \%$ interval. The Nominal Stage evaluation combined the nominal SB4 composition shown in Table 3-1 with each frit (listed in Table 3-2) at WLs from 25 through $60 \%$ (in increments of $1 \%$ ). The results (i.e., the operating windows for each of these glass systems) from this assessment for the frits in Table 3-2 are provided in Section 5.

\subsection{Overview of Variation Stage Assessments}

Given the Nominal Stage assessment does not account for any anticipated compositional variation in a sludge option, there is an increased risk with respect to processability or product quality if a decision (i.e., frit selection) were to be based solely on this assessment. The risk is reduced by the Variation Stage assessment, which is used to gain insight into the robustness of candidate frits with respect to sludge compositional variation. Table 4-1 provides the framework for the Variation Stage assessments for the nominal SB4 option being evaluated. These assessments replaced the nominal concentration for each oxide in the sludge with an interval (limited by minimum (min) and maximum ( $\max )$ values) of possible concentrations. The top two rows in Table 4-1 indicate the types of variation that were introduced to determine the minimums and maximums: a variation of $\pm 7.5 \%$ of the nominal value was placed around the nominal value to determine the min's and max's for the major oxides (i.e., $\mathrm{Al}_{2} \mathrm{O}_{3}, \mathrm{Fe}_{2} \mathrm{O}_{3}, \mathrm{MnO}, \mathrm{Na}_{2} \mathrm{O}$, and $\mathrm{U}_{3} \mathrm{O}_{8}$ ). $\mathrm{A} \pm 0.25 \mathrm{wt} \%$ variation was placed around the nominal value for each individually tracked minor oxide (i.e., $\mathrm{CaO}, \mathrm{MgO}, \mathrm{NiO}$, and $\mathrm{SiO}_{2}$ but not $\mathrm{SO}_{4}{ }^{\circ}$ ) and for "Others." The variation applied to the nominal $\mathrm{SO}_{4}{ }^{=}$value was $\pm 0.10 \mathrm{wt} \%$. The "Others" term was used to allow for the inclusion of the minor oxides that were not tracked individually. The composition of the "Others" component for the sludge option considered in this report is provided (each oxide is given as a weight percentage of "Others") in Table 4-2. 
Table 4-1. Variation Stage Bounding Region for SB4 February 2007 Sludge Option (wt\%).

\begin{tabular}{|c|c|c|c|c|c|c|c|c|c|c|c|c|}
\hline \multicolumn{13}{|l|}{ Traditional EVs } \\
\hline Variation & & 7.5 & 0.25 & 7.5 & 0.25 & 7.5 & 7.5 & 0.25 & 0.1 & 0.25 & 7.5 & 0.25 \\
\hline Unit of Measure & & $\%$ & $\mathbf{w t} \%$ & $\%$ & $\mathbf{w t} \%$ & $\mathbf{w t} \%$ & $\%$ & $\mathbf{w t} \%$ & $\mathbf{w t} \%$ & $\mathbf{w t} \%$ & $\mathbf{w t} \%$ & $\mathbf{w t} \%$ \\
\hline Option & & $\mathrm{Al}_{2} \mathrm{O}_{3}$ & $\mathrm{CaO}$ & $\mathrm{Fe}_{2} \mathrm{O}_{3}$ & MgO & $\mathrm{MnO}$ & $\mathrm{Na}_{2} \mathrm{O}$ & $\mathrm{NiO}$ & $\mathrm{SO}_{4}{ }^{=}$ & $\mathrm{SiO}_{2}$ & $\mathbf{U}_{3} \mathbf{O}_{8}$ & Others \\
\hline \multirow{2}{*}{$\begin{array}{c}\text { SB4 02-06-07 } \\
\text { Projection }\end{array}$} & Min & 22.965 & 2.608 & 27.684 & 2.644 & 5.507 & 16.210 & 1.454 & 0.995 & 2.550 & 8.675 & 0.787 \\
\hline & Max & 26.689 & 3.108 & 32.173 & 3.144 & 6.400 & 18.839 & 1.954 & 1.195 & 3.050 & 10.082 & 1.287 \\
\hline
\end{tabular}

Table 4-2. Components (wt\%) of "Others" for the SB4 February 2007 Option.

\begin{tabular}{|c|c|c|c|c|c|c|c|c|c|c|c|}
\hline & $\overline{\mathrm{BaO}}$ & 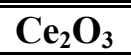 & 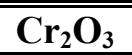 & 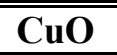 & $\mathrm{K}_{\mathbf{2}} \mathrm{O}$ & $\mathrm{La}_{\mathbf{2}} \mathrm{O}_{3}$ & PbO & $\mathrm{ThO}_{2}$ & $\mathrm{TiO}_{2}$ & $\mathrm{ZnO}$ & $\overline{\mathrm{ZrO}}$ \\
\hline $\begin{array}{c}\text { Components of } \\
\text { Others }\end{array}$ & 6.408 & 21.288 & 19.574 & 4.790 & 5.761 & 3.366 & 18.548 & 3.265 & 3.191 & 4.763 & 9.045 \\
\hline
\end{tabular}


Table 4-1 and Table 4-2 provide the framework around which the Variation Stage assessments were conducted. A sludge composition is in the region corresponding to this option if its concentration for each oxide is within the min and max interval for that oxide (e.g., the $\mathrm{Al}_{2} \mathrm{O}_{3}$ concentration in the sludge is between 22.965 and $26.689 \mathrm{wt} \%$ ) and the sum of the concentrations of all of the oxides in the sludge equals 100. Such a composition is a mixture of oxides at concentrations that correspond to one of the possible compositions for that sludge option as defined by Table 4-1. Algorithms are available in statistical software packages such as JMP Version 6.0.2 (SAS 2005) to generate the compositions that are the "corner points" of the bounding region defined by Table 4-1 for a particular sludge option. The bounding "corner-point" compositions generated by JMP are called the extreme vertices (EVs) of the sludge region.

For the "Others" component, the concentration for an EV was generated by JMP. This concentration was then expanded into the oxides comprising "Others" using the percentages of Table 4-2. The centroid (or average of the EVs) for the sludge region was also generated so that it may be tracked during the Variation Stage to ensure consistent results with the Nominal Stage assessment. ${ }^{6}$ There were 1900 EVs that defined the bounding sludge compositional region.

Based on the results of the Nominal Stage assessments, primary frits of interest were then combined with the EVs generated by JMP at waste loadings from 25 to $60 \%$. The specific frits used in the Variation Stage were: Frit 418, Frit 425, Frit 503, Frit 505, Frit 509, Frit 510, and Frit 511. Frit 418 was assessed given the potential for its use through the SB3 - SB4 transition and perhaps during initial processing of SB4. The 500 series of frits are of particular interest given the higher $\mathrm{B}_{2} \mathrm{O}_{3}$ contents and the potential for improved melt rates. The resulting glass compositions were evaluated against the PCCS MAR criteria to determine their respective acceptability. A frit is considered to demonstrate robustness to the variation in a sludge option if $100 \%$ of the EVs for that option meet the PCCS MAR criteria over a wide sub-interval of the 25 to $60 \%$ WL interval. In addition, where less than $100 \%$ of the EVs are acceptable, identifying the constraint or constraints that are not met (i.e., the constraint(s) that limit the operating window) is of interest.

\subsection{PROJECTED OPERATING WINDOWS}

In this section, the projected operating windows are presented for the Nominal and Variation Stage assessments for the SB4 option. Exhibit A1 in Appendix A provides the details of the MAR results that were generated from the Nominal Stage assessments for the candidate frits of Table 3-2. Table 5-1 summarizes the Nominal Stage assessments for the $8 \% \mathrm{~B}_{2} \mathrm{O}_{3}$ based frits including Frit 418 . Table 5-2 summarizes the Nominal Stage assessments for the $14 \% \mathrm{~B}_{2} \mathrm{O}_{3}$ based frits (i.e., the 500 series). Exhibit A2 in Appendix A provides the details of the MAR results that were generated from the Variation Stage assessments. Table 5-1 and Table 5-2 also include the results on the Variation Stage assessments for select systems. The intent of the tables is to provide the reader with an easily accessible reference for comparing the operating windows of the February 2007 SB4 projection for various frits of interest. These comparisons may suggest an advantage, based upon the perspective of this paper study, of one frit over the other as these results will play a critical role in the frit recommendation for SB4.

\subsection{Nominal Stage and Variation Stage Assessments}

As stated above, Exhibits A1 and A2 in Appendix A provide the detailed results of the Nominal and Variation Stage assessments. Table 5-1 summarizes the results (projected operating windows) of the 8\% $\mathrm{B}_{2} \mathrm{O}_{3}$ based frits including Frit 418 (a primary candidate for SB4 processing). Table 5-2 summarizes the

\footnotetext{
${ }^{6}$ It should be noted that the nominal composition and the centroid are not exactly the same but they will be extremely close. Therefore, their projected operating windows should be relatively close in size.
} 
results for the $14 \% \mathrm{~B}_{2} \mathrm{O}_{3}$ based frits (i.e., the 500 series). The constraint that limits either or both ends of the WL interval is also indicated. In addition, the nominal frit compositions are shown in each table to aid the reader in determining how frit composition affects the projected operating window. The "Nepheline Active" column represents the WL at which predictions using the nepheline discriminator and the 0.62 value suggest nepheline could form and ultimately have a negative impact on durability. It should be noted that there has been recent data that suggest that the use of high $\mathrm{B}_{2} \mathrm{O}_{3}$ based frits actually suppresses nepheline formation, and thus the use of the 0.62 value may lead to a conservative limit on WL. The "Melt Rate" column represents an estimate of the anticipated melt rates for each system. These estimates are based on recent Melt Rate Furnace (MRF) and Slurry-Fed Melt Rate Furnace (SMRF) (Smith et al. (2006)) testing with the June 2006 SB4 compositions. This testing indicated: (a) higher $\mathrm{Na}_{2} \mathrm{O}$ concentrations at a fixed $\mathrm{B}_{2} \mathrm{O}_{3}$ content $(8 \%)$ improved melt rate (specifically the trends in melt rate with Frit 418, 425, and 320) and (b) increasing $\mathrm{B}_{2} \mathrm{O}_{3}$ concentrations (Frit 503 with 14\%) had a significant, positive impact on melt rate even though $\mathrm{Na}_{2} \mathrm{O}$ contents were relatively low (4\% as compared to $8 \%$ in Frit 418, 10\% in Frit 425, and 12\% in Frit 320). The results of the MRF tests are shown in Figure 5-1. Smith et al. (2006) evaluated Frit 418, Frit 425, and Frit 503 with the June 2006 composition at 35\% WL. Those results indicated no significant differences in melt rate between Frit 418 and Frit $425(11.5 \mathrm{~g} / \mathrm{min}$ versus $11.6 \mathrm{~g} / \mathrm{min}$, respectively) while the higher $\mathrm{B}_{2} \mathrm{O}_{3}$ based frit (Frit 503) showed a significant increase in melt rate $(13.1 \mathrm{~g} / \mathrm{min})$.

These melt rate trends were used to guide the selection of frits for the Nominal and Variation Stage assessments. More specifically, it was assumed that the higher $\mathrm{B}_{2} \mathrm{O}_{3}$ based frits and/or higher $\mathrm{Na}_{2} \mathrm{O}$ concentrations will improve melt rate for SB4. Although the compositional projections have changed from June 2006 to February 2007, frit development efforts will assume the same trends hold. This does induce some risk but that risk is seen as being low. Again, the use of high and low in the "Melt Rate" columns in Table 5-1 and Table 5-2 are based on these assumptions. It should be noted that there are programs in place to confirm these trends for the February 2007 composition but these data are not available at this time.

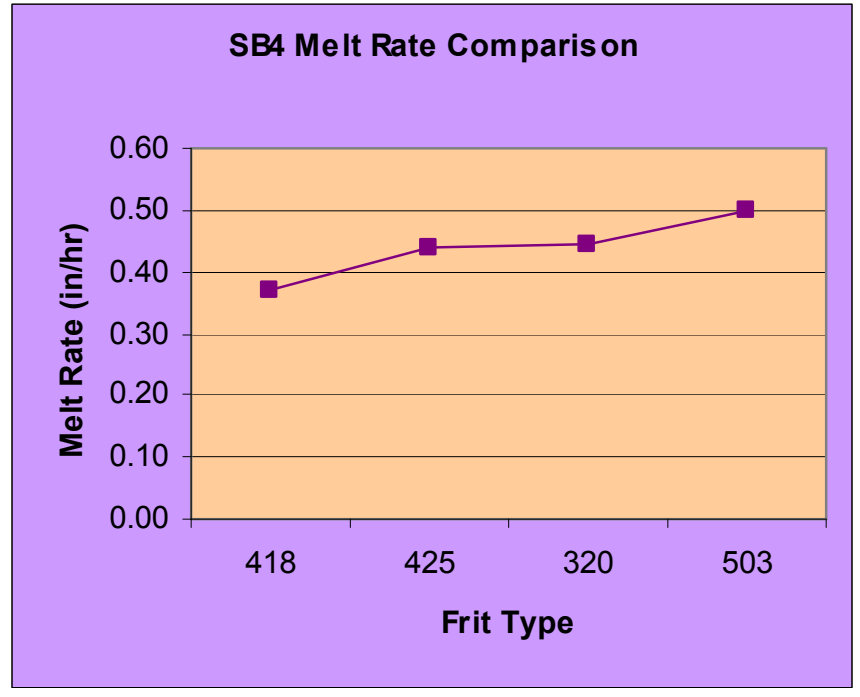

Figure 5-1. Preliminary MRF Results Using the June 2006 SB4 Projections. 
WSRC-STI-2007-00088

Revision 0

\subsubsection{8\% $\mathrm{B}_{2} \mathrm{O}_{3}$ Based Frits}

This series of frits has as its cornerstone Frit 418, which is currently being used to process SB3 and is a primary candidate for the transition between SB3 and SB4 as well as initial processing of SB4. This series of frits has a fixed $\mathrm{B}_{2} \mathrm{O}_{3}$ content of $8 \mathrm{wt} \%$ and varies the $\mathrm{Na}_{2} \mathrm{O}$ concentration from $8 \%$ (Frit 418) to $12 \%$ (Frit 320) in an attempt to accommodate the $\mathrm{Na}_{2} \mathrm{O}$ concentration of the sludge given the washing and blending strategy proposed by the February 2007 composition. A review of the projected operating windows for the February 2007 composition as a function of this frit series is provided below. As previously noted, impacts of an imposed $\mathrm{SO}_{4}{ }^{3}$ limit were not activated in this assessment (see Section 5.2 for more details).

The Nominal Stage assessment for the Frit 418 based glass system yields a projected operating window of $25-41 \% \mathrm{WL}$. At $42 \% \mathrm{WL}$, the system becomes $\mathrm{T}_{\mathrm{L}}$ limited given the relatively low $\mathrm{Na}_{2} \mathrm{O}$ content of the frit. As $\mathrm{Na}_{2} \mathrm{O}$ concentrations in the frit increase (from Frit 418 to Frit 425), the predicted $\mathrm{T}_{\mathrm{L}} \mathrm{S}$ decrease, which allows access to higher WLs. More specifically, the use of Frit 425 with SB4 has a projected operating window of $25-43 \%$ with the system being $\mathrm{T}_{\mathrm{L}}$ limited. Further increases in the frit $\mathrm{Na}_{2} \mathrm{O}$ content transitions the systems from being $T_{L}$ limited to nepheline limited with Frit 417 and Frit 320. Assuming DWPF wants to avoid processing a system that could be product quality limited (since nepheline is linked to durability), Frits 418,417 , and 425 are primary candidates for SB4 processing. ${ }^{7}$ Based on the preliminary SB4 melt rate data (see Figure 5-1), higher melt rates may be achieved as the $\mathrm{Na}_{2} \mathrm{O}$ concentration in the frit increases. It would therefore be anticipated that Frit 425 would yield the higher melt rate (although the SMRF data indicated no significant difference in melt rate when compared to Frit 418).

Based on the Nominal Stage results, Frit 418 and Frit 425 were carried forward to the Variation Stage assessment and the results are also presented in Table 5-1. The WL intervals over which all 1900 EVs could be processed for Frit 418 and Frit 425 are $26-37 \%$ and $25-39 \%$, respectively, with both systems being $T_{L}$ limited. Predictions of high viscosity limit approximately $7 \%$ of the 1900 EVs from being processed at $25 \% \mathrm{WL}$ for the Frit 418 based system. Based on the results, both frits provided a high degree of robustness to potential sludge variation with Frit 425 having a slight advantage. Given its potential advantage in melt rate (based on historical MRF trends) and the Nominal and Variation Stage results, Frit 425 should also be considered a primary candidate for processing SB4. A potential disadvantage (albeit slight) for Frit 425 is the smaller WL delta between the maximum upper WL prior to becoming $\mathrm{T}_{\mathrm{L}}$ limited (43\%) and the WL at which nepheline could potentially become an issue (46\%). It should be noted that this issue assumes that maximum waste throughput would be achieved at WLs of $40 \%$ or greater for SB4 - and that probability is rather low. With Frit 418, that WL delta is $7 \%$ but again, the potential for forming nepheline at the WLs of interest in either system is extremely low.

\footnotetext{
${ }^{7}$ It should be noted that if the addition of $\mathrm{Na}_{2} \mathrm{O}$ resulted in the transition of a particular glass system from $\mathrm{T}_{\mathrm{L}}$ to nepheline limited at sufficiently high WLs (e.g., $25-48 \%$ WL being nepheline limited at $49 \%$ WL), this system would be of interest given the impact of WL on melt rate. More specifically, based on historical trends, DWPF would probably not target WLs in the mid-tohigh 40's due to melt rate and/or waste throughput issues; therefore, having a system that is nepheline limited at extremely high WLs would not be grounds for excluding the frit as a candidate for DWPF processing.
} 
Table 5-1. Nominal and Variation Stage Assessment Results for the $8 \% \mathrm{~B}_{2} \mathrm{O}_{3}$ Based Frits.

\begin{tabular}{|c|c|c|c|c|c|c|c|c|}
\hline \multirow[b]{2}{*}{ Frit ID } & \multirow[b]{2}{*}{$\mathbf{B}_{\mathbf{2}} \mathbf{O}_{3}$} & \multirow[b]{2}{*}{$\overline{\mathbf{L i}_{2} \mathbf{O}}$} & \multirow[b]{2}{*}{$\mathbf{N a}_{2} \mathbf{O}$} & \multirow[b]{2}{*}{$\overline{\mathrm{SiO}_{2}}$} & \multicolumn{2}{|c|}{$\begin{array}{c}\text { Projected } \\
\text { Operating Window }\end{array}$} & \multirow{2}{*}{$\begin{array}{c}\begin{array}{c}\text { Nepheline } \\
\text { Active }\end{array} \\
\text { Nominal }\end{array}$} & \multirow{2}{*}{$\begin{array}{c}\text { Relative } \\
\text { Melt Rate } \\
(? ?) \\
\end{array}$} \\
\hline & & & & & Nominal & Variation & & \\
\hline 320 & 8 & 8 & 12 & 72 & $\begin{array}{c}25-42 \\
\text { Neph }\end{array}$ & NA & $43 \%$ & High \\
\hline 417 & 8 & 8 & 11 & 73 & $\begin{array}{l}25-43 \\
\text { Neph }\end{array}$ & NA & $44 \%$ & \\
\hline 425 & 8 & 8 & 10 & 74 & $\begin{array}{c}25-43 \\
T_{L}\end{array}$ & $\begin{array}{c}25-39 \\
T_{L}\end{array}$ & $46 \%$ & \\
\hline 426 & 8 & 8 & 9 & 75 & $\begin{array}{c}25-42 \\
T_{L}\end{array}$ & NA & $47 \%$ & \\
\hline 418 & 8 & 8 & 8 & 76 & $\begin{array}{c}25-41 \\
\mathrm{~T}_{\mathrm{L}}\end{array}$ & $\begin{array}{c}\text { high } \eta \\
26-37 \\
T_{L}\end{array}$ & $48 \%$ & Low \\
\hline
\end{tabular}

\subsection{2 $14 \% \mathrm{~B}_{2} \mathrm{O}_{3}$ Based Frits}

Table 5-2 summarizes the Nominal and Variation Stage assessments for the $14 \% \mathrm{~B}_{2} \mathrm{O}_{3}$ based frits (or the 500 series). Based on the June 2006 compositions (with relatively high $\mathrm{Na}_{2} \mathrm{O}$ contents as compared to the February 2007 projection - see Table 3-1), Frit 503 was recommended for SB4 processing (Peeler et al. (2006a)). As previously noted, the higher $\mathrm{B}_{2} \mathrm{O}_{3}$ based frits (14\%) were developed for two primary reasons: (1) higher $\mathrm{B}_{2} \mathrm{O}_{3}$ may potentially suppress nepheline formation and (2) higher $\mathrm{B}_{2} \mathrm{O}_{3}$ concentrations appear to lead to higher melt rates for higher $\mathrm{Al}_{2} \mathrm{O}_{3}$ based feeds based on the MRF and SMRF data (Smith et al. (2006)). However, coupling Frit 503 with the lower $\mathrm{Na}_{2} \mathrm{O}$ based February 2007 sludge, results in a very restricted operating window (i.e., $25-35 \% \mathrm{WL}$ and $\mathrm{T}_{\mathrm{L}}$ limited at higher WLs). Once variation is accounted for, the operating window is nearly non-existent with all of the EVs being processable only from $30-32 \% \mathrm{WL}$. Given these results, Frit 503 is not a primary candidate for the February 2007 SB4 projection. As with the $8 \% \mathrm{~B}_{2} \mathrm{O}_{3}$ based frits, as $\mathrm{Na}_{2} \mathrm{O}$ contents increase, relief from the $\mathrm{T}_{\mathrm{L}}$ restrictions does occur. More specifically, as one transitions from the $4 \% \mathrm{Na}_{2} \mathrm{O}$ in Frit 503 to $9 \%$ $\mathrm{Na}_{2} \mathrm{O}$ in Frit 511, the projected operating windows continually expand as predictions of $\mathrm{T}_{\mathrm{L}}$ become less restrictive. With Frit 511 , the projected operating window is $25-41 \% \mathrm{WL}$ with predictions of $\mathrm{T}_{\mathrm{L}}$ limiting access to higher WLs. Further increases in the $\mathrm{Na}_{2} \mathrm{O}$ concentration transition the glass systems from being $\mathrm{T}_{\mathrm{L}}$ limited to low viscosity limited for Frit 512. In fact the transition from Frit 511 to Frit 512 (a $1 \%$ increase in $\mathrm{Na}_{2} \mathrm{O}$ ) not only shifts the system to become low viscosity limited but it has a significant, negative impact on the operating window size (i.e., Frit 512's operating window is $25-38 \% \mathrm{WL}$ ). The sensitivity of the projected operating window to a $1 \% \mathrm{Na}_{2} \mathrm{O}$ change in frit provides a degree of uncertainty that will be accounted for in the frit selection process. Assuming melt rate trends increase with increasing $\mathrm{Na}_{2} \mathrm{O}$ concentration, Frit 511 would be an ideal candidate for SB4 processing. The projected operating windows are at their highest (for both the Nominal and Variation Stage), the systems are process constraint limited ( $\mathrm{T}_{\mathrm{L}}$ and/or low viscosity), but the sensitivity of the system to minor compositional changes in frit reduces its attractiveness. In fact, selecting Frit 510 over Frit 511 may be the more favorable approach (i.e., less risk) given the operating windows allow WLs in the upper 30s to be targeted. The system appears less susceptible to minor $\mathrm{Na}_{2} \mathrm{O}$ differences in the frit, and nepheline formation is not an issue until WLs in the mid-40s. The only potential disadvantage may be a reduction in melt rate assuming the $1 \%$ additional $\mathrm{Na}_{2} \mathrm{O}$ in Frit 511 provides a significant, positive impact on melt rate. 
Table 5-2. Nominal and Variation Stage Assessment Results for the 14\% $\mathrm{B}_{2} \mathrm{O}_{3}$ Based Frits.

\begin{tabular}{|c|c|c|c|c|c|c|c|c|}
\hline \multirow[b]{2}{*}{ Frit ID } & \multirow[b]{2}{*}{$\mathrm{B}_{2} \mathrm{O}_{3}$} & \multirow[b]{2}{*}{$\mathbf{L i}_{2} \mathbf{O}$} & \multirow[b]{2}{*}{$\mathrm{Na}_{2} \mathrm{O}$} & \multirow[b]{2}{*}{$\mathrm{SiO}_{2}$} & \multicolumn{2}{|c|}{$\begin{array}{c}\text { Projected } \\
\text { Operating Window }\end{array}$} & \multirow{2}{*}{$\begin{array}{c}\begin{array}{c}\text { Nepheline } \\
\text { Active }\end{array} \\
\text { Nominal }\end{array}$} & \multirow{2}{*}{$\begin{array}{c}\text { Relative } \\
\text { Melt Rate } \\
\text { (??) } \\
\end{array}$} \\
\hline & & & & & Nominal & Variation & & \\
\hline $\begin{array}{c}512 \\
(503-\mathrm{m} 5)\end{array}$ & 14 & 8 & 10 & 68 & $\begin{array}{c}25-38 \\
\text { low } \eta\end{array}$ & NA & $43 \%$ & High \\
\hline $\begin{array}{c}511 \\
(503-\mathrm{m} 4) \\
\end{array}$ & 14 & 8 & 9 & 69 & $\begin{array}{c}25-41 \\
T_{L} \\
\end{array}$ & $\begin{array}{r}25-37 \\
\text { low } \eta / T_{L}\end{array}$ & $44 \%$ & \\
\hline $\begin{array}{c}510 \\
(503-\mathrm{m} 3) \\
\end{array}$ & 14 & 8 & 8 & 70 & $\begin{array}{c}25-40 \\
T_{L} \\
\end{array}$ & $\begin{array}{c}25-36 \\
\mathrm{~T}_{\mathrm{L}} \\
\end{array}$ & $45 \%$ & \\
\hline $\begin{array}{c}509 \\
(503-\mathrm{m} 2)\end{array}$ & 14 & 8 & 7 & 71 & $\begin{array}{c}25-39 \\
T_{L}\end{array}$ & $\begin{array}{c}25-35 \\
T_{L}\end{array}$ & $46 \%$ & \\
\hline 505 & 14 & 8 & 6 & 72 & $\begin{array}{c}25-38 \\
T_{L}\end{array}$ & $\begin{array}{c}25-34 \\
\mathrm{~T}_{\mathrm{L}}\end{array}$ & $48 \%$ & \\
\hline $\begin{array}{c}508 \\
(503-\mathrm{m} 1)\end{array}$ & 14 & 8 & 5 & 73 & $\begin{array}{c}25-37 \\
T_{L}\end{array}$ & NA & $49 \%$ & \\
\hline 503 & 14 & 8 & 4 & 74 & $\begin{array}{c}25-35 \\
\mathrm{~T}_{\mathrm{L}}\end{array}$ & $\begin{array}{c}\text { high } \eta \\
30-32 \\
\mathrm{~T}_{\mathrm{L}}\end{array}$ & $50 \%$ & Low \\
\hline
\end{tabular}

\subsection{Impact of $\mathrm{SO}_{4}{ }^{=}$}

In the MAR assessments of the sludge composition discussed above (both Nominal and Variation Stages), the $\mathrm{SO}_{4}{ }^{\prime}$ concentrations in the glass were calculated, but an assumed $\mathrm{SO}_{4}{ }^{=}$limit was not used to restrict the projected operating windows. Given there is no MAR uncertainty associated with the $\mathrm{SO}_{4}{ }^{=}$ concentration, the maximum WL for each sludge projection can be determined as a function of an assumed $\mathrm{SO}_{4}{ }^{\circ}$ solubility limit based strictly on mathematics (i.e., the assumed $\mathrm{SO}_{4}{ }^{2}$ solubility limit divided by the $\mathrm{SO}_{4}{ }^{2}$ concentration in sludge multiplied by 100). For example, the $\mathrm{SO}_{4}{ }^{-}$concentration in the February 2007 sludge was $1.09 \mathrm{wt} \%$ and if the assumed $\mathrm{SO}_{4}{ }^{=}$solubility limit was $0.6 \mathrm{wt} \%$ (in glass), then the maximum WL achievable (based strictly on the $\mathrm{SO}_{4}{ }^{=}$solubility limit) would be $\sim 55 \mathrm{wt} \%$. If the $\mathrm{SO}_{4}{ }{ }$ solubility limit were $0.5 \mathrm{wt} \%$ or $0.4 \mathrm{wt} \%$, then the maximum achievable WLs (based strictly on the $\mathrm{SO}_{4}{ }^{=}$solubility limit) for this case would be approximately $45 \%$ and $37 \%$, respectively.

From a historical SB4 perspective, Fox et al. (2006c) provided preliminary results that indicated that the $0.6 \mathrm{wt} \% \mathrm{SO}_{4}{ }{ }^{2}$ solubility limit (defined for the Frit 418 - SB3 system) was applicable for earlier SB4 projections. In that study, a series of glasses based on Frit 418 and Frit 503 was spiked with varying levels of $\mathrm{SO}_{4}{ }^{=}$(targeting 0.6 up to $0.8 \mathrm{wt} \%$ in glass). More specifically, five Frit 418 based glasses were fabricated at $38 \% \mathrm{WL}$ with the glasses being spiked with $\mathrm{SO}_{4}{ }^{=}$from 0.6 to 0.8 in $0.05 \mathrm{wt} \%$ increments. An additional five glasses were also made based on the Frit 503 - SB4 system at 38\% WL which were also spiked with $\mathrm{SO}_{4}{ }^{2}$. No sulfur salt layer was visually observed on any of the study glasses after pouring and quenching. Based on the measured compositions, sulfate volatilization occurred in all of the study glasses, as evidenced by measured sulfate concentrations that fell below the targeted values. However, the glasses that targeted the highest sulfate concentrations using either Frit 418 or Frit 503 retained sulfate at concentrations at or above the previous limit of $0.6 \mathrm{wt} \%$ established for SB3 processing. These results imply that the $0.6 \mathrm{wt} \% \mathrm{SO}_{4}{ }^{=}$solubility limit may be extended to SB4 processing. However, it was recognized that the $\mathrm{SO}_{4}{ }^{\circ}$ solubility limit is a function of overall glass 
composition and with the February 2007 composition serving as the baseline, these recent experimental data provide only a cursory assessment of the direct applicability of the $0.6 \mathrm{wt} \%$ limit.

Based on the Nominal and Variation Stage assessments, Frit 510 appears to be a leading candidate for SB4 processing. In addition, Frit 418 may be used during the transition from SB3 to SB4 and could be used during the initial processing of SB4. Although glasses will be fabricated to assess the $\mathrm{SO}_{4}{ }^{=}$ solubility limit in both Frit 418 and Frit 510 based glasses, Jantzen and Smith (2003) also linked $\mathrm{SO}_{4}{ }^{=}$ solubility to viscosity. Sulfate solubility was modeled against the calculated DWPF viscosity model so that the DWPF could take advantage of the higher sulfate solubilities associated with more fluid melts.

The sulfate solubility - viscosity relationship defines three parallel correlations for the various degrees of sulfate saturation. Jantzen and Smith (2003) showed that the Upper 95\% (U95) individual confidence limit of the "at saturation" sulfate correlation (no visible molten salt layer) is conservative to both over saturation and supersaturation conditions. The "at saturation U95" sulfate solubility limit may be approximated by the following relationship (Jantzen and Smith (2003)):

$$
\left.\mathrm{SO}_{4}{ }^{=} \text {solubility (at saturation) }\right)_{\mathrm{U} 95}=1.5333-0.5585 \log \text { viscosity }_{\text {calc }} \text { (poise) }
$$

This sulfate solubility-composition relationship will allow a $\mathrm{SO}_{4}{ }^{=}$solubility of $0.81 \mathrm{wt} \%$ at the DWPF lower viscosity limit of 20 poise, and a $\mathrm{SO}_{4}{ }^{=}$solubility of $0.39 \mathrm{wt} \%$ at the DWPF upper viscosity limit of 110 poise. A melter feed with a calculated glass viscosity of 50 poise will have a $\mathrm{SO}_{4}{ }^{=}$solubility of 0.58 wt $\%$.

Given the recent SB4 $\mathrm{SO}_{4}{ }^{-}$data provided by Fox et al. (2006c), an assessment of the predicted $\mathrm{SO}_{4}{ }^{=}$ concentrations (based on or related to viscosity) as compared to actual concentrations measured in glass may provide insight into the solubility limit for SB4 for both Frit 418 and Frit 510. Table 5-3 summarizes the predicted viscosities and $\mathrm{SO}_{4}{ }^{\circ}$ solubility limits for the June $2006 \mathrm{SB} 4$ systems for both glasses as a function of $\mathrm{SO}_{4}{ }^{2}$ spiking concentration. Given the experimental glasses for the Frit 418 systems targeted a $38 \% \mathrm{WL}$ glass, the viscosity predictions (46 Poise) and the predict $\mathrm{SO}_{4}{ }{ }$ solubility limits $(0.6 \mathrm{wt} \%)$ are essentially constant. The same can be said about the Frit 503 based glasses with a predicted viscosity of $\sim 47$ Poise and a calculated $\mathrm{SO}_{4}{ }^{=}$limit of $0.6 \mathrm{wt} \%$. Both glass systems retained more than the $0.6 \mathrm{wt} \%$ calculated limit indicating that not only is the $0.6 \mathrm{wt} \%$ limit potentially applicable but that the model predictions associated with $\mathrm{SO}_{4}{ }^{2}$ retention could be conservative.

Table 5-3. Predicted $\mathrm{SO}_{4}{ }^{=}$Solubility Limits for Various June $2006 \mathrm{SB} 4$ Systems.

\begin{tabular}{|c|c|c|c|c|}
\hline $\begin{array}{c}\% \\
\mathrm{SO}_{4}\end{array}$ & Frit & $\begin{array}{c}\text { Predicted } \\
\text { Viscosity } \\
\text { (Poise) }\end{array}$ & $\begin{array}{c}\mathrm{SO}_{4}{ }^{*} \text { Solubility } \\
\text { Limit Prediction }\end{array}$ & $\begin{array}{c}\text { Measured } \mathrm{SO}_{4}{ }^{=} \\
(\mathrm{wt} \% \text { in glass) }\end{array}$ \\
\hline 0.6 & 418 & 46.43 & 0.60 & 0.49 \\
\hline 0.65 & 418 & 46.42 & 0.60 & 0.56 \\
\hline 0.7 & 418 & 46.34 & 0.60 & 0.57 \\
\hline 0.75 & 418 & 46.29 & 0.60 & 0.65 \\
\hline 0.8 & 418 & 46.47 & 0.60 & 0.66 \\
\hline 0.6 & 503 & 47.87 & 0.60 & 0.52 \\
\hline 0.65 & 503 & 47.74 & 0.60 & 0.54 \\
\hline 0.7 & 503 & 47.77 & 0.60 & 0.55 \\
\hline 0.75 & 503 & 47.64 & 0.60 & 0.62 \\
\hline 0.8 & 503 & 47.83 & 0.60 & 0.61 \\
\hline
\end{tabular}


In the absence of experimental data, this same approach can be used to assess the $\mathrm{SO}_{4}{ }^{\circ}$ solubility limit for the Frit 418 and Frit 510 systems based on the February 2007 SB4 composition. The solubility viscosity relationship was used to assess the predicted solubility limits of glasses at 30, 35, and 40\% WL. Table 5-4 summarizes the results of this assessment. For the Frit 418 system, predicted viscosities range from $\sim 80$ Poise at $30 \% \mathrm{WL}$ down to $\sim 59$ Poise at 40\% WL. The corresponding $\mathrm{SO}_{4}{ }^{=}$limits range from $0.471 \mathrm{wt} \%$ (at $30 \% \mathrm{WL}$ ) up to $0.543 \mathrm{wt} \%$ (at 40\% WL). Assuming DWPF processes SB4 with Frit 418 at a nominal $35 \% \mathrm{WL}$ and recognizing that the model predictions could be conservative, a $0.5 \mathrm{wt} \% \mathrm{PCCS}$ $\mathrm{SO}_{4}{ }^{=}$limit may need to be utilized. As previously discussed, use of a $0.5 \mathrm{wt} \%$ PCCS limit would restrict WLs for the nominal SB4 February 2007 composition to $\sim 45 \%$ or less. The projected operating window based on the Nominal Stage assessment for the Frit 418 system was $25-41 \%$ WL with predictions of $\mathrm{T}_{\mathrm{L}}$ limiting access to higher WLs. In this case, even with the $0.5 \mathrm{wt} \% \mathrm{PCCS}$ limit, $\mathrm{SO}_{4}{ }^{=}$solubility issues are not limiting.

For the Frit 510 based system, the predicted $\mathrm{SO}_{4}{ }^{=}$solubility limits are $0.6 \mathrm{wt} \%$ and greater over the $30-$ $40 \% \mathrm{WL}$ interval (see Table 5-4). Assuming the predictions are conservative, the results suggest that implementation of the $0.6 \mathrm{wt} \%$ limit for the Frit 510 - SB4 system is technically viable and defensible. Even if a $0.5 \mathrm{wt} \%$ limit were implemented (which would restrict WLs to $45 \%$ ), the projected operating window for the Frit 510 - February $2007 \mathrm{SB} 4$ composition is $25-40 \% \mathrm{WL}$. Again, $\mathrm{SO}_{4}{ }^{=}$solubility issues would still not be the limiting factor at the lower $0.5 \mathrm{wt} \%$ limit. As previously mentioned, experimental data is not currently available for the Frit 510 and/or Frit 418 based SB4 systems to assess $\mathrm{SO}_{4}{ }^{=}$retention.

Table 5-4. Predicted $\mathrm{SO}_{4}{ }^{=}$Solubility Limits Using the February 2007 SB4 Composition.

\begin{tabular}{||c|c|c|c||}
\hline $\begin{array}{c}\mathbf{\%} \\
\text { WL }\end{array}$ & Frit & $\begin{array}{c}\text { Predicted } \\
\text { Viscosity (Poise) }\end{array}$ & $\begin{array}{c}\mathbf{S O}_{4}{ }^{\circ} \text { Solubility } \\
\text { Limit Prediction }\end{array}$ \\
\hline 30 & 418 & 79.75 & 0.471 \\
\hline 35 & 418 & 69.51 & 0.505 \\
\hline 40 & 418 & 59.29 & 0.543 \\
\hline 30 & 510 & 45.34 & 0.608 \\
\hline 35 & 510 & 39.16 & 0.644 \\
\hline 40 & 510 & 33.05 & 0.685 \\
\hline
\end{tabular}

\subsection{IMPACT TO SB4 VARIABILITY STUDY}

Assuming the frit recommendation for the February 2007 SB4 projection is either Frit 418 or Frit 510, a major question to be addressed is: "Is there a need to complete a variability study for the compositional region of interest based on the latest SB4 projections?" Variability studies have been completed using Frit 418 and Frit 503 for earlier SB4 projections (Fox et al. (2006d) and (2006e)). These previous studies have shown that the glasses within the compositional region defined by the earlier sludge projections, frit compositions, and WL range of interest are acceptable (i.e., they are durable products) and the current durability models are applicable. 
To determine if a supplemental study would be required, an evaluation can be made to see if there is overlap between the compositional regions of interest and experimental data from historical glasses (contained within the ComPro or Nepheline databases). Consider the use of Frit 418 with the February $2007 \mathrm{SB} 4$ composition. In terms of $\mathrm{B}_{2} \mathrm{O}_{3}$ and $\mathrm{Na}_{2} \mathrm{O}$ concentrations (the two primary components of interest), the MAR acceptable EVs (from Section 5.1) can be mapped (see green mapped region in Figure 6-1). This region represents the EVs and centroid compositions that are MAR acceptable as a function of WL. If Frit 510 is used to process SB4, the pink region in Figure 6-1 maps the MAR acceptable compositional region of interest. If historical glasses adequately cover the compositional regions of interest and the glasses are both acceptable and predictable, a decision can be made that a supplemental variability study is not required. A computational search of the ComPro and Nepheline databases found several glasses that lie within and around both compositional regions of interest for the February 2007 SB4 composition. Glasses from the Frit 503 Variability Study (Fox et al. (2006d)) and the Phase 4 nepheline formation study (Fox et al. (2006b)) provide ample coverage within the Frit 510 February 2007 SB4 region of interest. Glasses from the Frit 418 Variability Study (Fox et al. (2006e)) and Nepheline Phase 3 studies (Fox et al. (2006f)) provide adequate coverage within the Frit 418 February 2007 region of interest. Given the historical glasses shown in Figure 6-1 are both acceptable and predictable, if Frit 510 and/or Frit 418 are used to process SB4, a supplemental variability study is not required.

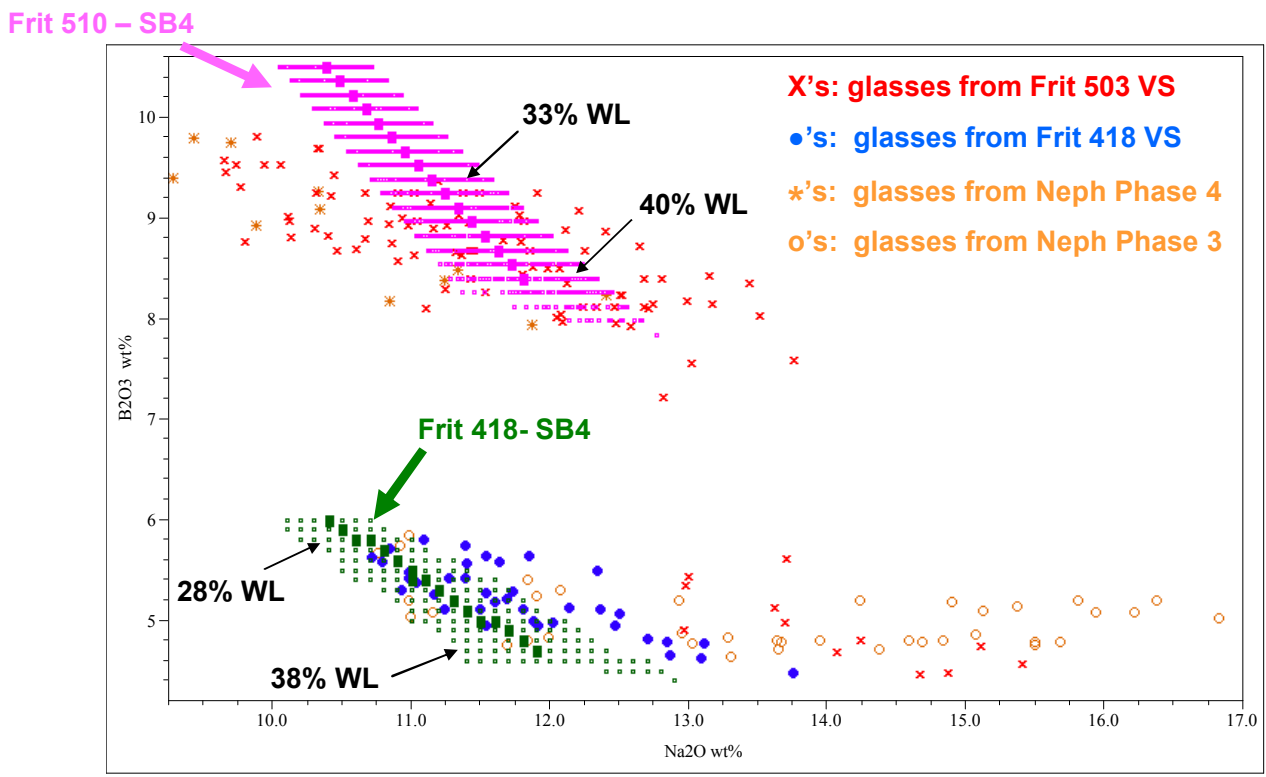

Figure 6-1. Historical Glasses with the Frit 510 - SB4 and Frit 418 - SB4Compositional Regions of Interest. 
WSRC-STI-2007-00088

Revision 0

\subsection{SUMMARY}

This report documents the results of SRNL's efforts to identify candidate frit compositions and corresponding predicted operating windows (defined in terms of WL intervals) for the February 2007 compositional projection of Sludge Batch 4 (SB4) developed by the Liquid Waste Organization (LWO). The nominal compositional projection was used to assess projected operating windows (in terms of a waste loading interval over which all predicted properties were classified as acceptable) for various frits, evaluate the applicability of the $0.6 \mathrm{wt} \% \mathrm{SO}_{4}{ }^{=}$PCCS limit to the glass systems of interest, and determine the impact (or lack thereof) to the previous SB4 variability studies. It should be mentioned that the information from this report will be coupled with assessments of melt rate from which a frit recommendation will be made.

The results of this paper study suggest that candidate frits are available to process the nominal SB4 composition over attractive waste loadings of interest to DWPF. Specifically, two primary candidate frits for SB4 processing, Frit 510 and Frit 418, have projected operating windows that should allow for successful processing at DWPF. While Frit 418 has been used at DWPF, Frit 510 is a higher $\mathrm{B}_{2} \mathrm{O}_{3}$ based frit which could lead to improvements in melt rate. These frits provide relatively large operating windows and demonstrate robustness to possible sludge compositional variation while avoiding potential nepheline formation issues. In addition, assessments of $\mathrm{SO}_{4}{ }^{=}$solubility indicate that the $0.6 \mathrm{wt} \% \mathrm{SO}_{4}{ }^{=}$ limit in PCCS is applicable for the Frit 418 and the Frit 510 based SB4 glass systems.

\subsection{PATH FORWARD}

Based on the results of this study, the following recommendations are made:

(1) Perform melt rate tests with Frit 418 and Frit 510 (at a minimum) and the revised composition

(2) Fabricate a series of Frit 510 glasses to assess the PCT response as well as $\mathrm{SO}_{4}{ }^{=}$solubility

(3) Based on the melt rate results and the MAR assessments provided in this study, recommend a frit to DWPF for SB4 processing. 
WSRC-STI-2007-00088

Revision 0

\subsection{REFERENCES}

ASTM 2002. Standard Test Methods for Determining Chemical Durability of Nuclear Waste Glasses: The Product Consistency Test (PCT), ASTM C-1285-2002.

Brown KG, CM Jantzen, and G Ritzhaupt. 2001. Relating Liquidus Temperature to Composition for Defense Waste Processing Facility (DWPF) Process Control, WSRC-TR-2001-00520, Revision 0, Westinghouse Savannah River Company, Aiken, South Carolina.

Brown, KG, RL Postles, and TB Edwards, 2006. SME Acceptability Determination for DWPF Process Control, WSRC-TR-95-0364, Revision 5, Westinghouse Savannah River Company, Aiken, South Carolina.

Edwards, TB, DK Peeler, and SL Marra. 2003. Revisiting the Prediction Limits for Acceptable Durability, WSRC-TR-2003-00510, Revision 0, Westinghouse Savannah River Company, Aiken, South Carolina.

Edwards, TB, DK Peeler, and KM Fox. 2006. The Nepheline Discriminator: Justification and DWPF PCCS Implementation Details, WSRC-STI-2006-00014, Washington Savannah River Company, Aiken, South Carolina.

Fox, KM, TB Edwards, DK Peeler, DR Best, IA Reamer, and RJ Workman. 2006a. Nepheline Formation Study for Sludge Batch 4 (SB4): Phase 3 Experimental Results, WSRC-TR-2006-00093, Revision 0, Washington Savannah River Company, Aiken, South Carolina.

Fox, KM, TB Edwards, DK Peeler, DR Best, IA Reamer, and RJ Workman. 2006b. Durability and Nepheline Crystallization Study for High Level Waste (HLW) Sludge Batch 4 (SB4) Glasses Formulated with Frit 503, WSRC-STI-2006-00009, Revision 0, Washington Savannah River Company, Aiken, South Carolina.

Fox, KM, TB Edwards, and DK Peeler. 2006c. Sulfate Retention in High Level Waste (HLW) Sludge Batch 4 (SB4) Glasses: A Preliminary Assessment, WSRC-STI-2006-00038, Revision 0, Washington Savannah River Company, Aiken, South Carolina.

Fox, KM, TB Edwards, DK Peeler, DR Best, IA Reamer, and RJ Workman. 2006d. High Level Waste (HLW) Sludge Batch 4 (SB4) Variability Study, WSRC-STI-2006-00204, Revision 0, Washington Savannah River Company, Aiken, South Carolina.

Fox, KM, TB Edwards, DK Peeler, DR Best, IA Reamer, and RJ Workman. 2006e. High Level Waste (HLW) Sludge Batch 4 (SB4) With Frit 418: Results of a Phase II Variability Study, WSRC-STI2006-00329, Revision 0, Washington Savannah River Company, Aiken, South Carolina.

Fox, KM, DK Peeler, TB Edwards, DR Best, IA Reamer, and RJ Workman, 2006f, Nepheline Formation Study for Sludge Batch 4 (SB4): Phase 3 Experimental Results, WSRC-TR-2006-00093, Revision 0, Washington Savannah River Company, Aiken, South Carolina.

Jantzen, CM, JB Pickett, KG Brown, TB Edwards, and DC Beam. 1995. Process/Product Models for the Defense Waste Processing Facility (DWPF): Part I. Predicting Glass Durability from 
Composition Using a Thermodynamic Hydration Energy Reaction Model (THERMO) (U), WSRCTR-93-672, Revision 1, Volume 1, Westinghouse Savannah River Company, Aiken, South Carolina.

Jantzen, CM. 2005. The Impacts of Uranium and Thorium on the Defense Waste Processing Facility (DWPF) Viscosity Model, WSRC-TR-2004-00311, Revision 0, Westinghouse Savannah River Company, Aiken, South Carolina.

Janzten, CM and ME Smith. 2003. Revision of the Defense Waste Processing Facility (DWPF) Sulfate Solubility Limit, WSRC-TR-2003-00518, Revision 0, Westinghouse Savannah River Company, Aiken, South Carolina.

Li, H, P Hrma, JD Vienna, M Qian, Y Su, and DE Smith. 2003. Effects of $\mathbf{A l}_{\mathbf{2}} \mathbf{O}_{3}, \mathbf{B}_{2} \mathbf{O}_{3}, \mathbf{N a} \mathbf{a}_{\mathbf{2}} \mathbf{O}$, and $\mathrm{SiO}_{2}$ on Nepheline Formation in Borosilicate Glasses: Chemical and Physical Correlations, Journal of Non-Crystalline Solids, 331, pgs. $202-216$.

Peeler, DK and TB Edwards. 2002. Frit Development for Sludge Batch 3, WSRC-TR-2002-00491, Revision 0, Westinghouse Savannah River Company, Aiken, South Carolina.

Peeler, DK. 2004. Task Technical \& QA Plan: Sludge Batch and MCU Frit Optimization, WSRCRP-2004-00746, Revision 0, Westinghouse Savannah River Company, Aiken, South Carolina.

Peeler, DK, TB Edwards, IA Reamer, and RJ Workman. 2005. Nepheline Formation Study for Sludge Batch 4 (SB4): Phase 1 Experimental Results, WSRC-TR-2005-00371, Revision 0, Westinghouse Savannah River Company, Aiken, South Carolina.

Peeler, DK, TB Edwards, and KM Fox. 2006a. Frit Recommendation for SB4, SRNL-PSE-200600128, Revision 0, Washington Savannah River Company, Aiken, South Carolina.

Peeler, DK, TB Edwards, IA Reamer, and RJ Workman. 2006b. Nepheline Formation Study for Sludge Batch 4 (SB4): Phase 2 Experimental Results, WSRC-TR-2006-00006, Revision 0, Washington Savannah River Company, Aiken, South Carolina.

Shah, HB. 2007. Estimate of Sludge Batch 4 and 5 Calcine Compositions for SRNL, LWO-PIT-200700017, Revision 0, Washington Savannah River Company, Aiken, South Carolina.

Smith, ME, ME Stone, TM Jones, DH Miller, and PR Burket. 2006. Sludge Batch 4 Melt Rate Furnace and Slurry-Fed Melt Rate Furnace Tests with Frits 418, 425, and 503, WSRC-STI-2006-00015, Revision 0, Washington Savannah River Company, Aiken, South Carolina.

SAS Institute, Inc. 2005. JMP® Statistics and Graphics Guide: JMP Version 6.0.2, SAS Institute, Inc., Cary, North Carolina.

Washburn, FA. 2004. Technical Task Request: Sludge Batch 4 and MCU Frit Optimization, HLW/DWPF/TTR-2004-0025, Revision 0, Westinghouse Savannah River Company, Aiken, South Carolina. 
WSRC-STI-2007-00088

Revision 0

This page intentionally left blank. 


\section{APPENDIX A}

\section{Nominal and Variation Stage MAR Assessments}


Exhibit A1. Results of the Nominal Stage MAR Assessments for the February 2007 SB4 Composition.

\begin{tabular}{|c|c|c|c|c|c|c|c|c|c|}
\hline$\% \mathrm{WL}$ & 200 & 200-m1 & $200-\mathrm{m} 2$ & 202 & 320 & 417 & 418 & 418-m1/501 & $418-\mathrm{m} 10 / 503$ \\
\hline 25 & & & & hvisc & & & & & \\
\hline 26 & & & & hvisc & & & & & \\
\hline 27 & & & & hvisc & & & & & \\
\hline 28 & & & & hvisc & & & & & \\
\hline 29 & & & & hvisc & & & & & \\
\hline 30 & & & & hvisc & & & & & \\
\hline 31 & & & & hvisc & & & & & \\
\hline 32 & & & & hvisc & & & & & \\
\hline 33 & & & & hvisc & & & & & \\
\hline 34 & & & & hvisc & & & & & \\
\hline 35 & & & & TL hvisc & & & & & \\
\hline 36 & & & & TL hvisc & & & & & TL \\
\hline 37 & & & & TL hvisc & & & & & TL \\
\hline 38 & $\mathrm{TL}$ & & & TL & & & & & TL \\
\hline 39 & $\mathrm{TL}$ & TL & $\mathrm{TL}$ & $\mathrm{TL}$ & & & & & TL \\
\hline 40 & $\mathrm{TL}$ & TL & TL & $\mathrm{TL}$ & & & & TL & TL \\
\hline 41 & TL & TL & $\mathrm{TL}$ & TL & & & & $\mathrm{TL}$ & TL \\
\hline 42 & TL & TL & TL & TL & & & TL & TL & TL \\
\hline 43 & TL Neph & TL & TL & TL & Neph & & TL & $\mathrm{TL}$ & $\mathrm{TL}$ \\
\hline 44 & TL Neph & TL & $\mathrm{TL}$ & TL & Neph & Neph & $\mathrm{TL}$ & $\mathrm{TL}$ & TL \\
\hline 45 & TL Neph & TL & TL & TL & Neph & TL Neph & TL & TL & TL \\
\hline 46 & TL Neph & TL & TL & TL & TL Neph & TL Neph & TL & TL & TL \\
\hline 47 & TL Neph & TL & TL & TL & TL lvisc Neph & TL Neph & $\mathrm{TL}$ & TL & $\mathrm{TL}$ \\
\hline 48 & TL Neph & TL & $\mathrm{TL}$ & $\mathrm{TL}$ & TL lvisc Neph & TL Neph & TL Neph & $\mathrm{TL}$ & $\mathrm{TL}$ \\
\hline 49 & TL Neph & TL & TL Neph & TL & TL lvisc Neph & TL Neph & TL Neph & TL & TL \\
\hline 50 & TL Neph & TL Neph & TL Neph & TL Neph & TL lvisc Neph & TL lvisc Neph & TL Neph & TL Neph & TL Neph \\
\hline 51 & TL Neph & TL Neph & TL Neph & TL Neph & TL lvisc Neph & TL lvisc Neph & TL Neph & TL Neph & TL Neph \\
\hline 52 & TL Neph & TL Neph & TL Neph & TL Neph & TL lvisc Neph & TL lvisc Neph & TL Neph & TL Neph & TL Neph \\
\hline 53 & TL Neph & TL Neph & TL Neph & TL Neph & TL lvisc Neph & TL lvisc Neph & TL Neph & TL Neph & TL Neph \\
\hline 54 & TL Neph & TL Neph & TL Neph & TL Neph & TL lvisc Neph & TL lvisc Neph & TL Neph & TL Neph & TL Neph \\
\hline 55 & TL lvisc Neph & TL Neph & TL lvisc Neph & TL Neph & TL lvisc Neph & TL lvisc Neph & TL Neph & TL Neph & TL Neph \\
\hline 56 & TL lvisc Neph & TL Neph & TL lvisc Neph & TL Neph & TL lvisc Neph & TL lvisc Neph & TL Neph & TL lvisc Neph & TL Neph \\
\hline 57 & TL lvisc Neph & TL Neph & TL lvisc Neph & TL Neph & TL lvisc Neph & TL lvisc Neph & TL Neph & TL lvisc Neph & TL Neph \\
\hline 58 & TL lvisc Neph & TL lvisc Neph & TL lvisc Neph & TL Neph & TL lvisc Neph & TL lvisc Neph & TL lvisc Neph & TL lvisc Neph & TL lvisc Neph \\
\hline 59 & TL lvisc Neph & TL lvisc Neph & TL lvisc Neph & TL Neph & TL lvisc Neph & TL lvisc Neph & TL lvisc Neph & TL lvisc Neph & TL lvisc Neph \\
\hline 60 & TL lvisc Neph & TL lvisc Neph & TL lvisc Neph & TL Neph & TL lvisc Neph & TL lvisc Neph & TL lvisc Neph & TL lvisc Neph & TL lvisc Neph \\
\hline
\end{tabular}


WSRC-STI-2007-00088

Revision 0

\begin{tabular}{|c|c|c|c|c|c|c|c|c|c|}
\hline$\% \mathrm{WL}$ & $418-\mathrm{m} 11$ & $418-\mathrm{m} 12$ & 418-m13 & 418-m14/504 & 418-m15 & 418-m16 & 418-m17 & 418-m18 & 418-m19 \\
\hline 25 & hvisc & & & & & & & & \\
\hline 26 & hvisc & & & & & & & & \\
\hline 27 & hvisc & & & & & & & & \\
\hline 28 & hvisc & & & & & & & & \\
\hline 29 & hvisc & & & & & & & & \\
\hline 30 & hvisc & & & & & & & & \\
\hline \multicolumn{10}{|l|}{31} \\
\hline \multicolumn{10}{|l|}{32} \\
\hline \multicolumn{10}{|l|}{33} \\
\hline \multicolumn{10}{|l|}{34} \\
\hline \multicolumn{10}{|l|}{35} \\
\hline 36 & & TL & TL & TL & & & & & \\
\hline 37 & TL & $\mathrm{TL}$ & TL & TL & & & $\mathrm{TL}$ & TL & TL \\
\hline 38 & $\mathrm{TL}$ & TL & $\mathrm{TL}$ & $\mathrm{TL}$ & $\mathrm{TL}$ & $\mathrm{TL}$ & $\mathrm{TL}$ & $\mathrm{TL}$ & $\mathrm{TL}$ \\
\hline 39 & TL & $\mathrm{TL}$ & TL & TL & TL & $\mathrm{TL}$ & TL & TL & $\mathrm{TL}$ \\
\hline 40 & $\mathrm{TL}$ & $\mathrm{TL}$ & $\mathrm{TL}$ & $\mathrm{TL}$ & $\mathrm{TL}$ & $\mathrm{TL}$ & $\mathrm{TL}$ & $\mathrm{TL}$ & $\mathrm{TL}$ \\
\hline 41 & TL & TL & TL & TL & TL & TL & $\mathrm{TL}$ & TL & TL \\
\hline 42 & TL & $\mathrm{TL}$ & $\mathrm{TL}$ & TL & $\mathrm{TL}$ & $\mathrm{TL}$ & $\mathrm{TL}$ & $\mathrm{TL}$ & TL \\
\hline 43 & TL & $\mathrm{TL}$ & TL & TL & TL & $\mathrm{TL}$ & TL & TL & TL \\
\hline 44 & $\mathrm{TL}$ & $\mathrm{TL}$ & $\mathrm{TL}$ & $\mathrm{TL}$ & $\mathrm{TL}$ & $\mathrm{TL}$ & $\mathrm{TL}$ & $\mathrm{TL}$ & TL lvisc \\
\hline 45 & TL & TL & TL & TL & $\mathrm{TL}$ & TL & TL & TL & TL lvisc \\
\hline 46 & TL & TL & TL & TL & TL & TL & $\mathrm{TL}$ & TL & TL lvisc Neph \\
\hline 47 & $\mathrm{TL}$ & TL & $\mathrm{TL}$ & TL lvisc Neph & TL & $\mathrm{TL}$ & $\mathrm{TL}$ & TL Neph & TL lvisc Neph \\
\hline 48 & $\mathrm{TL}$ & $\mathrm{TL}$ & TL Neph & TL lvisc Neph & $\mathrm{TL}$ & $\mathrm{TL}$ & TL Neph & TL lvisc Neph & TL lvisc Neph \\
\hline 49 & $\mathrm{TL}$ & TL Neph & TL Neph & TL lvisc Neph & TL Neph & TL Neph & TL Neph & TL lvisc Neph & TL lvisc Neph \\
\hline 50 & TL Neph & TL Neph & TL Neph & TL 1visc Neph & TL Neph & TL Neph & TL Neph & TL lvisc Neph & TL lvisc Neph \\
\hline 51 & TL Neph & TL Neph & TL Neph & TL lvisc Neph & TL Neph & TL Neph & TL Neph & TL lvisc Neph & TL lvisc Neph \\
\hline 52 & TL Neph & TL Neph & TL lvisc Neph & TL lvisc Neph & TL Neph & TL Neph & TL lvisc Neph & TL lvisc Neph & TL lvisc Neph \\
\hline 53 & TL Neph & TL Neph & TL lvisc Neph & TL lvisc Neph & TL Neph & TL Neph & TL lvisc Neph & TL lvisc Neph & TL lvisc Neph \\
\hline 54 & TL Neph & TL Neph & TL lvisc Neph & TL lvisc Neph & TL Neph & TL Neph & TL lvisc Neph & TL lvisc Neph & TL lvisc Neph \\
\hline 55 & TL Neph & TL lvisc Neph & TL lvisc Neph & TL lvisc Neph & TL Neph & TL Neph & TL lvisc Neph & TL lvisc Neph & TL lvisc Neph \\
\hline 56 & TL Neph & TL lvisc Neph & TL lvisc Neph & TL lvisc Neph & TL Neph & TL Neph & TL lvisc Neph & TL lvisc Neph & TL lvisc Neph \\
\hline 57 & TL Neph & TL lvisc Neph & TL lvisc Neph & TL lvisc Neph & TL lvisc Neph & TL Neph & TL lvisc Neph & TL lvisc Neph & TL lvisc Neph \\
\hline 58 & TL Neph & TL lvisc Neph & TL lvisc Neph & TL lvisc Neph & TL lvisc Neph & TL Neph & TL lvisc Neph & TL lvisc Neph & TL lvisc Neph \\
\hline 59 & TL Neph & TL lvisc Neph & TL lvisc Neph & TL lvisc Neph & TL lvisc Neph & TL lvisc Neph & TL lvisc Neph & TL lvisc Neph & TL lvisc Neph \\
\hline 60 & TL Neph & TL lvisc Neph & TL lvisc Neph & TL lvisc Neph & TL lvisc Neph & TL lvisc Neph & TL lvisc Neph & TL lvisc Neph & TL lvisc Neph \\
\hline
\end{tabular}


WSRC-STI-2007-00088

Revision 0

\begin{tabular}{|c|c|c|c|c|c|c|c|c|c|}
\hline$\% \mathrm{WL}$ & 418-m2 & 418-m20/505 & 418-m21 & $418-\mathrm{m} 22$ & 418-m23/506 & 418-m24 & 418-m25 & 418-m26 & 418-m28/507 \\
\hline 25 & hvisc & & & & & & & & \\
\hline 26 & hvisc & & & & & & & TL & \\
\hline 27 & hvisc & & & & & & & $\mathrm{TL}$ & \\
\hline 28 & hvisc & & & & & & & $\mathrm{TL}$ & \\
\hline 29 & & & & & & & TL & TL & \\
\hline 30 & & & & & & & $\mathrm{TL}$ & $\mathrm{TL}$ & \\
\hline 31 & & & & & & & $\mathrm{TL}$ & $\mathrm{TL}$ & \\
\hline 32 & & & & & & $\mathrm{TL}$ & $\mathrm{TL}$ & $\mathrm{TL}$ & \\
\hline 33 & & & & & & $\mathrm{TL}$ & $\mathrm{TL}$ & $\mathrm{TL}$ & \\
\hline 34 & & & & & $\mathrm{TL}$ & $\mathrm{TL}$ & $\mathrm{TL}$ & $\mathrm{TL}$ & $\mathrm{TL}$ \\
\hline 35 & $\mathrm{TL}$ & & & & $\mathrm{TL}$ & $\mathrm{TL}$ & $\mathrm{TL}$ & $\mathrm{TL}$ & $\mathrm{TL}$ \\
\hline 36 & TL & & & & $\mathrm{TL}$ & $\mathrm{TL}$ & TL & $\mathrm{TL}$ & $\mathrm{TL}$ \\
\hline 37 & TL & & & & TL & TL & TL & TL & TL \\
\hline 38 & TL & & & $\mathrm{TL}$ & TL & $\mathrm{TL}$ & TL & $\mathrm{TL}$ & $\mathrm{TL}$ \\
\hline 39 & TL & $\mathrm{TL}$ & $\mathrm{TL}$ & TL & $\mathrm{TL}$ & $\mathrm{TL}$ & $\mathrm{TL}$ & $\mathrm{TL}$ & $\mathrm{TL}$ \\
\hline 40 & TL & $\mathrm{TL}$ & TL & TL & $\mathrm{TL}$ & $\mathrm{TL}$ & $\mathrm{TL}$ & $\mathrm{TL}$ & TL lvisc \\
\hline 41 & TL & $\mathrm{TL}$ & TL & $\mathrm{TL}$ & TL & TL & $\mathrm{TL}$ & $\mathrm{TL}$ & TL lvisc \\
\hline 42 & $\mathrm{TL}$ & TL & $\mathrm{TL}$ & $\mathrm{TL}$ & TL & $\mathrm{TL}$ & $\mathrm{TL}$ & $\mathrm{TL}$ & TL lvisc \\
\hline 43 & TL & $\mathrm{TL}$ & TL & $\mathrm{TL}$ & $\mathrm{TL}$ & $\mathrm{TL}$ & $\mathrm{TL}$ & TL lvisc & TL lvisc \\
\hline 44 & TL & $\mathrm{TL}$ & $\mathrm{TL}$ & $\mathrm{TL}$ & $\mathrm{TL}$ & $\mathrm{TL}$ & $\mathrm{TL}$ & TL lvisc & TL lvisc \\
\hline 45 & TL & TL & TL & TL lvisc & TL lvisc & TL & TL & TL lvisc & TL lvisc \\
\hline 46 & TL & TL & $\mathrm{TL}$ & TL lvisc Neph & TL lvisc Neph & TL & $\mathrm{TL}$ & TL lvisc Neph & TL lvisc \\
\hline 47 & TL & TL & TL Neph & TL lvisc Neph & TL lvisc Neph & $\mathrm{TL}$ & TL Neph & TL lvisc Neph & TL lvisc Neph \\
\hline 48 & TL & TL Neph & TL Neph & TL lvisc Neph & TL lvisc Neph & TL Neph & TL lvisc Neph & TL lvisc Neph & TL lvisc Neph \\
\hline 49 & $\mathrm{TL}$ & TL Neph & TL lvisc Neph & TL lvisc Neph & TL lvisc Neph & TL Neph & TL lvisc Neph & TL lvisc Neph & TL lvisc Neph \\
\hline 50 & TL Neph & TL Neph & TL lvisc Neph & TL lvisc Neph & TL lvisc Neph & TL Neph & TL lvisc Neph & TL lvisc Neph & TL lvisc Neph \\
\hline 51 & TL Neph & TL Neph & TL lvisc Neph & TL lvisc Neph & TL lvisc Neph & TL Neph & TL lvisc Neph & TL lvisc Neph & TL lvisc Neph \\
\hline 52 & TL Neph & TL Neph & TL lvisc Neph & TL lvisc Neph & TL lvisc Neph & TL lvisc Neph & TL lvisc Neph & TL lvisc Neph & TL lvisc Neph \\
\hline 53 & TL Neph & TL lvisc Neph & TL lvisc Neph & TL lvisc Neph & TL lvisc Neph & TL lvisc Neph & TL lvisc Neph & TL lvisc Neph & TL lvisc Neph \\
\hline 54 & TL Neph & TL lvisc Neph & TL lvisc Neph & TL lvisc Neph & TL lvisc Neph & TL lvisc Neph & TL lvisc Neph & TL lvisc Neph & TL lvisc Neph \\
\hline 55 & TL Neph & TL lvisc Neph & TL lvisc Neph & TL lvisc Neph & TL lvisc Neph & TL lvisc Neph & TL lvisc Neph & TL lvisc Neph & TL lvisc Neph \\
\hline 56 & TL Neph & TL lvisc Neph & TL lvisc Neph & TL lvisc Neph & TL lvisc Neph & TL lvisc Neph & TL lvisc Neph & TL lvisc Neph & TL lvisc Neph \\
\hline 57 & TL Neph & TL lvisc Neph & TL lvisc Neph & TL lvisc Neph & TL lvisc Neph & TL lvisc Neph & TL lvisc Neph & TL lvisc Neph & TL lvisc Neph \\
\hline 58 & TL Neph & TL lvisc Neph & TL lvisc Neph & TL lvisc Neph & TL lvisc Neph & TL lvisc Neph & TL lvisc Neph & TL lvisc Neph & TL lvisc Neph \\
\hline 59 & TL Neph & TL lvisc Neph & TL lvisc Neph & TL lvisc Neph & TL lvisc Neph & TL lvisc Neph & TL lvisc Neph & TL lvisc Neph & TL lvisc Neph \\
\hline 60 & TL lvisc Neph & TL lvisc Neph & TL lvisc Neph & TL lvisc Neph & TL lvisc Neph & TL lvisc Neph & TL lvisc Neph & TL lvisc Neph & TL lvisc Neph \\
\hline
\end{tabular}


WSRC-STI-2007-00088

Revision 0

\begin{tabular}{|c|c|c|c|c|c|c|c|c|c|}
\hline$\% \mathrm{WL}$ & 418-m29 & $418-\mathrm{m} 3$ & $418-\mathrm{m} 30$ & 418-m31 & 418-m32 & 418-m4 & 418-m5 & 418-m6 & 418-m7 \\
\hline 25 & & & & & & hvisc & hvisc & hvisc & \\
\hline 26 & & & lvisc & & & hvisc & hvisc & hvisc & \\
\hline 27 & & & lvisc & & & hvisc & hvisc & hvisc & \\
\hline 28 & & & lvisc & & & hvisc & & hvisc & \\
\hline 29 & & & TL lvisc & & & & & & \\
\hline 30 & & & TL lvisc & & & & & & \\
\hline 31 & & & TL lvisc & & & & & & \\
\hline 32 & $\mathrm{TL}$ & & TL lvisc & & TL & & & & \\
\hline 33 & $\mathrm{TL}$ & & TL lvisc & & $\mathrm{TL}$ & & & & \\
\hline 34 & TL lvisc & & TL lvisc & TL & TL & & & & \\
\hline 35 & TL 1visc & & TL lvisc & $\mathrm{TL}$ & $\mathrm{TL}$ & & & $\mathrm{TL}$ & \\
\hline 36 & TL lvisc & & TL lvisc & TL & TL & TL & & TL & \\
\hline 37 & TL lvisc & & TL lvisc & TL & $\mathrm{TL}$ & TL & & TL & \\
\hline 38 & TL lvisc & $\mathrm{TL}$ & TL lvisc & $\mathrm{TL}$ & TL & $\mathrm{TL}$ & $\mathrm{TL}$ & $\mathrm{TL}$ & $\mathrm{TL}$ \\
\hline 39 & TL lvisc & $\mathrm{TL}$ & TL lvisc & TL & $\mathrm{TL}$ & $\mathrm{TL}$ & TL & TL & $\mathrm{TL}$ \\
\hline 40 & TL lvisc & $\mathrm{TL}$ & TL lvisc & $\mathrm{TL}$ & $\mathrm{TL}$ & $\mathrm{TL}$ & $\mathrm{TL}$ & $\mathrm{TL}$ & $\mathrm{TL}$ \\
\hline 41 & TL lvisc & TL & TL lvisc & TL & TL & TL & $\mathrm{TL}$ & TL & TL \\
\hline 42 & TL lvisc & $\mathrm{TL}$ & TL lvisc & TL & $\mathrm{TL}$ & $\mathrm{TL}$ & $\mathrm{TL}$ & $\mathrm{TL}$ & $\mathrm{TL}$ \\
\hline 43 & TL lvisc & TL & TL lvisc & TL lvisc & TL & $\mathrm{TL}$ & TL & TL & TL \\
\hline 44 & TL lvisc & TL & TL lvisc & TL lvisc & TL lvisc & $\mathrm{TL}$ & $\mathrm{TL}$ & $\mathrm{TL}$ & $\mathrm{TL}$ \\
\hline 45 & TL lvisc & TL & TL lvisc Neph & TL 1visc & TL lvisc & TL & TL & TL & $\mathrm{TL}$ \\
\hline 46 & TL lvisc Neph & TL & TL lvisc Neph & TL 1visc & TL lvisc & $\mathrm{TL}$ & $\mathrm{TL}$ & $\mathrm{TL}$ & TL \\
\hline 47 & TL lvisc Neph & TL & TL lvisc Neph & TL lvisc Neph & TL lvisc Neph & $\mathrm{TL}$ & $\mathrm{TL}$ & $\mathrm{TL}$ & $\mathrm{TL}$ \\
\hline 48 & TL lvisc Neph & $\mathrm{TL}$ & TL lvisc Neph & TL lvisc Neph & TL lvisc Neph & $\mathrm{TL}$ & $\mathrm{TL}$ & $\mathrm{TL}$ & $\mathrm{TL}$ \\
\hline 49 & TL lvisc Neph & $\mathrm{TL}$ & TL lvisc Neph & TL lvisc Neph & TL lvisc Neph & $\mathrm{TL}$ & $\mathrm{TL}$ & $\mathrm{TL}$ & TL Neph \\
\hline 50 & TL lvisc Neph & TL Neph & TL lvisc Neph & TL lvisc Neph & TL lvisc Neph & TL Neph & TL Neph & TL Neph & TL Neph \\
\hline 51 & TL lvisc Neph & TL Neph & TL lvisc Neph & TL lvisc Neph & TL lvisc Neph & TL Neph & TL Neph & TL Neph & TL Neph \\
\hline 52 & TL lvisc Neph & TL Neph & TL lvisc Neph & TL lvisc Neph & TL lvisc Neph & TL Neph & TL Neph & TL Neph & TL Neph \\
\hline 53 & TL lvisc Neph & TL Neph & TL lvisc Neph & TL lvisc Neph & TL lvisc Neph & TL Neph & TL Neph & TL Neph & TL Neph \\
\hline 54 & TL lvisc Neph & TL Neph & TL lvisc Neph & TL lvisc Neph & TL lvisc Neph & TL Neph & TL Neph & TL Neph & TL Neph \\
\hline 55 & TL lvisc Neph & TL Neph & TL lvisc Neph & TL lvisc Neph & TL lvisc Neph & TL Neph & TL Neph & TL Neph & TL Neph \\
\hline 56 & TL lvisc Neph & TL Neph & TL lvisc Neph & TL lvisc Neph & TL lvisc Neph & TL Neph & TL Neph & TL Neph & TL Neph \\
\hline 57 & TL lvisc Neph & TL Neph & TL lvisc Neph & TL lvisc Neph & TL lvisc Neph & TL Neph & TL Neph & TL Neph & TL lvisc Neph \\
\hline 58 & TL lvisc Neph & TL lvisc Neph & TL lvisc Neph & TL lvisc Neph & TL lvisc Neph & TL Neph & TL Neph & TL Neph & TL lvisc Neph \\
\hline 59 & TL lvisc Neph & TL lvisc Neph & TL lvisc Neph & TL lvisc Neph & TL lvisc Neph & TL Neph & TL Neph & TL Neph & TL lvisc Neph \\
\hline 60 & TL lvisc Neph & TL lvisc Neph & TL lvisc Neph & TL lvisc Neph & TL lvisc Neph & TL lvisc Neph & TL lvisc Neph & TL lvisc Neph & TL lvisc Neph \\
\hline
\end{tabular}




\begin{tabular}{|c|c|c|c|c|c|c|c|c|c|}
\hline$\% \mathrm{WL}$ & 418-m8 & 418-m9 & 422 & 425 & 426 & 431 & 432 & 460 & 473 \\
\hline 25 & & & hvisc & & & & hvisc & hvisc & hvisc \\
\hline 26 & & & hvisc & & & & hvisc & hvisc & hvisc \\
\hline 27 & & & hvisc & & & & hvisc & & hvisc \\
\hline 28 & & & hvisc & & & & hvisc & & hvisc \\
\hline 29 & & & hvisc & & & & hvisc & & hvisc \\
\hline 30 & & & hvisc & & & & hvisc & & hvisc \\
\hline 31 & & & hvisc & & & & hvisc & & hvisc \\
\hline 32 & & & hvisc & & & & hvisc & & hvisc \\
\hline 33 & & & hvisc & & & & & & hvisc \\
\hline 34 & & & hvisc & & & & & & hvisc \\
\hline 35 & & & hvisc & & & & & & hvisc \\
\hline 36 & & & TL hvisc & & & & & & hvisc \\
\hline 37 & TL & TL & TL hvisc & & & & & & \\
\hline 38 & $\mathrm{TL}$ & $\mathrm{TL}$ & TL hvisc & & & & & & $\mathrm{TL}$ \\
\hline 39 & $\mathrm{TL}$ & $\mathrm{TL}$ & TL hvisc & & & & $\mathrm{TL}$ & & $\mathrm{TL}$ \\
\hline 40 & $\mathrm{TL}$ & $\mathrm{TL}$ & TL hvisc & & & & $\mathrm{TL}$ & & $\mathrm{TL}$ \\
\hline 41 & TL & TL & TL hvisc & & & & $\mathrm{TL}$ & TL & TL \\
\hline 42 & TL & $\mathrm{TL}$ & TL hvisc & & & Neph & $\mathrm{TL}$ & TL & TL \\
\hline 43 & TL & $\mathrm{TL}$ & TL hvisc & & TL & lvisc Neph & TL & TL & $\mathrm{TL}$ \\
\hline 44 & TL & TL & TL hvisc & TL & TL & lvisc Neph & TL & TL & TL \\
\hline 45 & TL & TL & $\mathrm{TL}$ & TL & TL & lvisc Neph & TL & TL & TL \\
\hline 46 & $\mathrm{TL}$ & TL & $\mathrm{TL}$ & TL Neph & TL & TL lvisc Neph & $\mathrm{TL}$ & $\mathrm{TL}$ & $\mathrm{TL}$ \\
\hline 47 & TL & TL & TL & TL Neph & TL Neph & TL lvisc Neph & TL & TL & TL \\
\hline 48 & $\mathrm{TL}$ & $\mathrm{TL}$ & $\mathrm{TL}$ & TL Neph & TL Neph & TL lvisc Neph & $\mathrm{TL}$ & $\mathrm{TL}$ & $\mathrm{TL}$ \\
\hline 49 & $\mathrm{TL}$ & $\mathrm{TL}$ & $\mathrm{TL}$ & TL Neph & TL Neph & TL lvisc Neph & $\mathrm{TL}$ & TL Neph & $\mathrm{TL}$ \\
\hline 50 & TL Neph & TL Neph & $\mathrm{TL}$ & TL Neph & TL Neph & TL lvisc Neph & TL Neph & TL Neph & $\mathrm{TL}$ \\
\hline 51 & TL Neph & TL Neph & TL & TL Neph & TL Neph & TL lvisc Neph & TL Neph & TL Neph & TL Neph \\
\hline 52 & TL Neph & TL Neph & $\mathrm{TL}$ & TL Neph & TL Neph & TL lvisc Neph & TL Neph & TL Neph & TL Neph \\
\hline 53 & TL Neph & TL Neph & TL Neph & TL lvisc Neph & TL Neph & TL lvisc Neph & TL Neph & TL Neph & TL Neph \\
\hline 54 & TL Neph & TL Neph & TL Neph & TL lvisc Neph & TL Neph & TL lvisc Neph & TL Neph & TL Neph & TL Neph \\
\hline 55 & TL Neph & TL Neph & TL Neph & TL lvisc Neph & TL Neph & TL lvisc Neph & TL Neph & TL Neph & TL Neph \\
\hline 56 & TL Neph & TL lvisc Neph & TL Neph & TL lvisc Neph & TL lvisc Neph & TL lvisc Neph & TL Neph & TL Neph & TL Neph \\
\hline 57 & TL lvisc Neph & TL lvisc Neph & TL Neph & TL lvisc Neph & TL lvisc Neph & TL lvisc Neph & TL Neph & TL Neph & TL Neph \\
\hline 58 & TL lvisc Neph & TL lvisc Neph & TL Neph & TL lvisc Neph & TL lvisc Neph & TL lvisc Neph & TL Neph & TL Neph & TL Neph \\
\hline 59 & TL lvisc Neph & TL lvisc Neph & TL Neph & TL lvisc Neph & TL lvisc Neph & TL lvisc Neph & TL Neph & TL Neph & TL Neph \\
\hline 60 & TL lvisc Neph & TL lvisc Neph & TL Neph & TL lvisc Neph & TL lvisc Neph & TL lvisc Neph & TL Neph & TL lvisc Neph & TL Neph \\
\hline
\end{tabular}


WSRC-STI-2007-00088

Revision 0

\begin{tabular}{|c|c|c|c|c|c|c|c|c|c|}
\hline$\% \mathrm{WL}$ & $503-\mathrm{ml}$ & $503-\mathrm{m} 10$ & $503-\mathrm{m} 2$ & $503-\mathrm{m} 3$ & 503-m4 & 503-m5 & 503-m6 & $503-\mathrm{m} 7$ & $503-\mathrm{m} 8$ \\
\hline \multicolumn{10}{|l|}{25} \\
\hline \multicolumn{10}{|l|}{26} \\
\hline \multicolumn{10}{|l|}{27} \\
\hline \multirow{2}{*}{\multicolumn{10}{|c|}{28}} \\
\hline \multicolumn{5}{|l|}{29} & & & & & \\
\hline \multicolumn{10}{|l|}{30} \\
\hline \multicolumn{10}{|l|}{31} \\
\hline 32 & & & & & & & & lvisc & \\
\hline 33 & & & & & & & & lvisc & \\
\hline 34 & & & & & & & & lvisc & \\
\hline 35 & & & & & & & & lvisc & \\
\hline 36 & & & & & & & & lvisc & \\
\hline 37 & & & & & & & & lvisc & \\
\hline 38 & $\mathrm{TL}$ & & & & & & & lvisc & $\mathrm{TL}$ \\
\hline 39 & TL & & & & & lvisc & & lvisc & $\mathrm{TL}$ \\
\hline 40 & $\mathrm{TL}$ & $\mathrm{TL}$ & $\mathrm{TL}$ & & & lvisc & & lvisc & $\mathrm{TL}$ \\
\hline 41 & TL & $\mathrm{TL}$ & TL & TL & & lvisc & $\mathrm{TL}$ & lvisc & TL \\
\hline 42 & $\mathrm{TL}$ & $\mathrm{TL}$ & $\mathrm{TL}$ & $\mathrm{TL}$ & $\mathrm{TL}$ & lvisc & TL lvisc & lvisc Neph & TL \\
\hline 43 & TL & $\mathrm{TL}$ & TL & TL & TL lvisc & TL lvisc Neph & TL lvisc & TL lvisc Neph & $\mathrm{TL}$ \\
\hline 44 & TL & TL Neph & $\mathrm{TL}$ & $\mathrm{TL}$ & TL lvisc Neph & TL lvisc Neph & TL lvisc Neph & TL lvisc Neph & $\mathrm{TL}$ \\
\hline 45 & TL & TL Neph & TL & TL Neph & TL lvisc Neph & TL lvisc Neph & TL lvisc Neph & TL lvisc Neph & TL \\
\hline 46 & TL & TL Neph & TL Neph & TL Neph & TL lvisc Neph & TL lvisc Neph & TL lvisc Neph & TL lvisc Neph & TL \\
\hline 47 & $\mathrm{TL}$ & TL Neph & TL Neph & TL lvisc Neph & TL lvisc Neph & TL lvisc Neph & TL lvisc Neph & TL lvisc Neph & $\mathrm{TL}$ \\
\hline 48 & $\mathrm{TL}$ & TL Neph & TL Neph & TL lvisc Neph & TL lvisc Neph & TL lvisc Neph & TL lvisc Neph & TL lvisc Neph & TL Neph \\
\hline 49 & TL Neph & TL Neph & TL Neph & TL lvisc Neph & TL lvisc Neph & TL lvisc Neph & TL lvisc Neph & TL lvisc Neph & TL Neph \\
\hline 50 & TL Neph & TL Neph & TL lvisc Neph & TL lvisc Neph & TL lvisc Neph & TL lvisc Neph & TL lvisc Neph & TL lvisc Neph & TL Neph \\
\hline 51 & TL Neph & TL Neph & TL lvisc Neph & TL lvisc Neph & TL lvisc Neph & TL lvisc Neph & TL lvisc Neph & TL lvisc Neph & TL Neph \\
\hline 52 & TL Neph & TL Neph & TL lvisc Neph & TL lvisc Neph & TL lvisc Neph & TL lvisc Neph & TL lvisc Neph & TL lvisc Neph & TL Neph \\
\hline 53 & TL Neph & TL Neph & TL lvisc Neph & TL lvisc Neph & TL lvisc Neph & TL lvisc Neph & TL lvisc Neph & TL lvisc Neph & TL Neph \\
\hline 54 & TL Neph & TL Neph & TL lvisc Neph & TL lvisc Neph & TL lvisc Neph & TL lvisc Neph & TL lvisc Neph & TL lvisc Neph & TL Neph \\
\hline 55 & TL Neph & TL Neph & TL lvisc Neph & TL lvisc Neph & TL lvisc Neph & TL lvisc Neph & TL lvisc Neph & TL lvisc Neph & TL Neph \\
\hline 56 & TL lvisc Neph & TL lvisc Neph & TL lvisc Neph & TL lvisc Neph & TL lvisc Neph & TL lvisc Neph & TL lvisc Neph & TL lvisc Neph & TL Neph \\
\hline 57 & TL lvisc Neph & TL lvisc Neph & TL lvisc Neph & TL lvisc Neph & TL lvisc Neph & TL lvisc Neph & TL lvisc Neph & TL lvisc Neph & TL lvisc Neph \\
\hline 58 & TL lvisc Neph & TL lvisc Neph & TL lvisc Neph & TL lvisc Neph & TL lvisc Neph & TL lvisc Neph & TL lvisc Neph & TL lvisc Neph & TL lvisc Neph \\
\hline 59 & TL lvisc Neph & TL lvisc Neph & TL lvisc Neph & TL lvisc Neph & TL lvisc Neph & TL lvisc Neph & TL lvisc Neph & TL lvisc Neph & TL lvisc Neph \\
\hline 60 & TL lvisc Neph & TL lvisc Neph & TL lvisc Neph & TL lvisc Neph & TL lvisc Neph & TL lvisc Neph & TL lvisc Neph & TL lvisc Neph & TL lvisc Neph \\
\hline
\end{tabular}


WSRC-STI-2007-00088

Revision 0

\begin{tabular}{|c|c|c|c|c|c|c|c|c|c|}
\hline$\% \mathrm{WL}$ & 503-m9 & d1-1 & P1-1 & P2-1 & P2-2 & $\mathrm{P} 2-3$ & P2-4 & P2-5 & P3-1/502 \\
\hline 25 & & hvisc & hvisc & & & & & & \\
\hline 26 & & hvisc & & & & & & & \\
\hline 27 & & hvisc & & & & & & & \\
\hline 28 & & hvisc & & & & & & & \\
\hline 29 & & hvisc & & & & & & & \\
\hline 30 & & hvisc & & & & & & & \\
\hline 31 & & hvisc & & & & & & & \\
\hline 32 & & hvisc & & & & & & & \\
\hline 33 & & hvisc & & & & & & & \\
\hline 34 & & hvisc & TL & & & & & & \\
\hline 35 & & hvisc & TL & & & & & & \\
\hline 36 & & hvisc & $\mathrm{TL}$ & TL & $\mathrm{TL}$ & & & & \\
\hline 37 & & TL hvisc & TL & TL & TL & & TL & $\mathrm{TL}$ & \\
\hline 38 & & TL hvisc & TL & TL & TL & $\mathrm{TL}$ & TL lvisc & TL & \\
\hline 39 & TL & TL hvisc & TL & TL & $\mathrm{TL}$ & $\mathrm{TL}$ & TL lvisc & TL & \\
\hline 40 & TL & TL hvisc & TL & TL & $\mathrm{TL}$ & $\mathrm{TL}$ & TL lvisc & TL & \\
\hline 41 & TL & TL & TL & TL & TL & TL & TL lvisc & TL lvisc & TL \\
\hline 42 & $\mathrm{TL}$ & TL & $\mathrm{TL}$ & TL & TL & $\mathrm{TL}$ & TL lvisc & TL lvisc & $\mathrm{TL}$ \\
\hline 43 & TL & TL & $\mathrm{TL}$ & $\mathrm{TL}$ & TL lvisc & $\mathrm{TL}$ & TL lvisc & TL lvisc & $\mathrm{TL}$ \\
\hline 44 & TL & $\mathrm{TL}$ & $\mathrm{TL}$ & TL & TL lvisc & $\mathrm{TL}$ & TL lvisc & TL lvisc & $\mathrm{TL}$ \\
\hline 45 & TL & TL & TL & TL & TL lvisc & TL & TL lvisc & TL lvisc & TL \\
\hline 46 & TL Neph & TL & $\mathrm{TL}$ & TL & TL lvisc & TL & TL lvisc & TL lvisc Neph & TL \\
\hline 47 & TL Neph & $\mathrm{TL}$ & $\mathrm{TL}$ & $\mathrm{TL}$ & TL lvisc & $\mathrm{TL}$ & TL lvisc Neph & TL lvisc Neph & $\mathrm{TL}$ \\
\hline 48 & TL Neph & TL & $\mathrm{TL}$ & TL & TL lvisc Neph & TL Neph & TL lvisc Neph & TL lvisc Neph & TL \\
\hline 49 & TL Neph & $\mathrm{TL}$ & TL Neph & TL Neph & TL lvisc Neph & TL Neph & TL lvisc Neph & TL lvisc Neph & $\mathrm{TL}$ \\
\hline 50 & TL Neph & TL & TL Neph & TL Neph & TL lvisc Neph & TL lvisc Neph & TL lvisc Neph & TL lvisc Neph & TL Neph \\
\hline 51 & TL Neph & TL & TL Neph & TL lvisc Neph & TL lvisc Neph & TL lvisc Neph & TL lvisc Neph & TL lvisc Neph & TL Neph \\
\hline 52 & TL Neph & TL Neph & TL Neph & TL lvisc Neph & TL lvisc Neph & TL lvisc Neph & TL lvisc Neph & TL lvisc Neph & TL Neph \\
\hline 53 & TL Neph & TL Neph & TL Neph & TL lvisc Neph & TL lvisc Neph & TL lvisc Neph & TL lvisc Neph & TL lvisc Neph & TL lvisc Neph \\
\hline 54 & TL Neph & TL Neph & TL Neph & TL lvisc Neph & TL lvisc Neph & TL lvisc Neph & TL lvisc Neph & TL lvisc Neph & TL lvisc Neph \\
\hline 55 & TL Neph & TL Neph & TL Neph & TL lvisc Neph & TL lvisc Neph & TL lvisc Neph & TL lvisc Neph & TL lvisc Neph & TL lvisc Neph \\
\hline 56 & TL Neph & TL Neph & TL Neph & TL lvisc Neph & TL lvisc Neph & TL lvisc Neph & TL lvisc Neph & TL lvisc Neph & TL lvisc Neph \\
\hline 57 & TL lvisc Neph & TL Neph & TL Neph & TL lvisc Neph & TL lvisc Neph & TL lvisc Neph & TL lvisc Neph & TL lvisc Neph & TL lvisc Neph \\
\hline 58 & TL lvisc Neph & TL Neph & TL Neph & TL lvisc Neph & TL lvisc Neph & TL lvisc Neph & TL lvisc Neph & TL lvisc Neph & TL lvisc Neph \\
\hline 59 & TL lvisc Neph & TL Neph & TL lvisc Neph & TL lvisc Neph & TL lvisc Neph & TL lvisc Neph & TL lvisc Neph & TL lvisc Neph & TL lvisc Neph \\
\hline 60 & TL lvisc Neph & TL Neph & TL lvisc Neph & TL lvisc Neph & TL lvisc Neph & TL lvisc Neph & TL lvisc Neph & TL lvisc Neph & TL lvisc Neph \\
\hline
\end{tabular}


WSRC-STI-2007-00088

Revision 0

\begin{tabular}{|c|c|c|c|c|c|c|}
\hline$\% \mathrm{WL}$ & P3-2 & P3-3 & P3-4 & $\mathrm{t} 1-1$ & $\mathrm{X} 1-1$ & Y1-1 \\
\hline 25 & & & & hvisc & $\Delta \mathrm{G}_{\mathrm{P}}$ & \\
\hline 26 & & & & hvisc & & \\
\hline 27 & & & & hvisc & & \\
\hline 28 & & & & hvisc & & \\
\hline 29 & & & & hvisc & & \\
\hline 30 & & & & hvisc & & \\
\hline 31 & & & & hvisc & & \\
\hline \multicolumn{7}{|l|}{32} \\
\hline 33 & & & & & & \\
\hline 34 & & & & & lvisc & \\
\hline 35 & & & & & lvisc & \\
\hline 36 & & & & TL & lvisc & \\
\hline 37 & & & & TL & lvisc & \\
\hline 38 & & & & TL & lvisc & \\
\hline 39 & & & & $\mathrm{TL}$ & lvisc Neph & lvisc \\
\hline 40 & & & & TL & lvisc Neph & lvisc Neph \\
\hline 41 & TL & & & TL & lvisc Neph & lvisc Neph \\
\hline 42 & TL & TL & & TL & lvisc Neph & lvisc Neph \\
\hline 43 & $\mathrm{TL}$ & TL & TL & $\mathrm{TL}$ & lvisc Neph & lvisc Neph \\
\hline 44 & TL & TL & TL & TL & lvisc Neph & lvisc Neph \\
\hline 45 & TL & TL & TL & TL & lvisc Neph & lvisc Neph \\
\hline 46 & TL & TL & TL & TL & lvisc Neph & lvisc Neph \\
\hline 47 & TL & TL & TL & TL & lvisc Neph & TL lvisc Neph \\
\hline 48 & TL & TL Neph & TL Neph & TL & TL lvisc Neph & TL lvisc Neph \\
\hline 49 & TL Neph & TL Neph & TL Neph & TL & TL lvisc Neph & TL lvisc Neph \\
\hline 50 & TL Neph & TL lvisc Neph & TL Neph & TL Neph & TL lvisc Neph & TL lvisc Neph \\
\hline 51 & TL Neph & TL lvisc Neph & TL Neph & TL Neph & TL lvisc Neph & TL lvisc Neph \\
\hline 52 & TL Neph & TL lvisc Neph & TL lvisc Neph & TL Neph & TL lvisc Neph & TL lvisc Neph \\
\hline 53 & TL lvisc Neph & TL lvisc Neph & TL lvisc Neph & TL Neph & TL lvisc Neph & TL lvisc Neph \\
\hline 54 & TL lvisc Neph & TL lvisc Neph & TL lvisc Neph & TL Neph & TL lvisc Neph & TL lvisc Neph \\
\hline 55 & TL lvisc Neph & TL lvisc Neph & TL lvisc Neph & TL Neph & TL lvisc Neph & TL lvisc Neph \\
\hline 56 & TL lvisc Neph & TL lvisc Neph & TL lvisc Neph & TL Neph & TL lvisc Neph & TL lvisc Neph \\
\hline 57 & TL lvisc Neph & TL lvisc Neph & TL lvisc Neph & TL Neph & TL lvisc Neph & TL lvisc Neph \\
\hline 58 & TL lvisc Neph & TL lvisc Neph & TL lvisc Neph & TL Neph & TL lvisc Neph & TL lvisc Neph \\
\hline 59 & TL lvisc Neph & TL lvisc Neph & TL lvisc Neph & TL Neph & TL lvisc Neph & TL lvisc Neph \\
\hline 60 & TL lvisc Neph & TL lvisc Neph & TL lvisc Neph & TL Neph & TL lvisc Neph & TL lvisc Neph \\
\hline
\end{tabular}


Exhibit A2. Results of the Variation Stage MAR Assessments for the February 2007 SB4 Composition.

\begin{tabular}{|c|c|c|c|c|c|c|c|c|c|c|c|c|c|c|}
\hline \multirow{3}{*}{$\begin{array}{c}\text { Sludge } \\
\text { Loading } \\
(\%)\end{array}$} & \multicolumn{2}{|c|}{$\begin{array}{c}\text { Variation Stage } \\
\text { Frit } 418\end{array}$} & \multicolumn{2}{|c|}{$\begin{array}{c}\text { Variation Stage } \\
\text { Frit } 425\end{array}$} & \multicolumn{2}{|c|}{$\begin{array}{c}\text { Variation Stage } \\
\text { Frit } 503\end{array}$} & \multicolumn{2}{|c|}{$\begin{array}{l}\text { Variation Stage } \\
\text { Frit 503-m4 / } 511\end{array}$} & \multicolumn{2}{|c|}{$\begin{array}{c}\text { Variation Stage } \\
\text { Frit 503-m2 / } 509\end{array}$} & \multicolumn{2}{|c|}{$\begin{array}{c}\text { Variation Stage } \\
\text { Frit } 505\end{array}$} & \multicolumn{2}{|c|}{$\begin{array}{c}\text { Variation Stage } \\
\text { Frit 503-m3 / } 510\end{array}$} \\
\hline & & $\%$ & & $\%$ & & $\%$ & & $\%$ & & $\%$ & & $\%$ & & $\%$ \\
\hline & Centroid & EVs & Centroid & EVs & Centroid & EVs & Centroid & EVs & Centroid & EVs & Centroid & EVs & Centroid & EVs \\
\hline 25 & & 93.4 & & 100.0 & & 75.4 & & 100.0 & & 100.0 & & 100.0 & & 100.0 \\
\hline 26 & & 100.0 & & 100.0 & & 78.9 & & 100.0 & & 100.0 & & 100.0 & & 100.0 \\
\hline 27 & & 100.0 & & 100.0 & & 84.9 & & 100.0 & & 100.0 & & 100.0 & & 100.0 \\
\hline 28 & & 100.0 & & 100.0 & & 92.2 & & 100.0 & & 100.0 & & 100.0 & & 100.0 \\
\hline 29 & & 100.0 & & 100.0 & & 99.3 & & 100.0 & & 100.0 & & 100.0 & & 100.0 \\
\hline 30 & & 100.0 & & 100.0 & & 100.0 & & 100.0 & & 100.0 & & 100.0 & & 100.0 \\
\hline 31 & & 100.0 & & 100.0 & & 100.0 & & 100.0 & & 100.0 & & 100.0 & & 100.0 \\
\hline 32 & & 100.0 & & 100.0 & & 100.0 & & 100.0 & & 100.0 & & 100.0 & & 100.0 \\
\hline 33 & & 100.0 & & 100.0 & & 98.8 & & 100.0 & & 100.0 & & 100.0 & & 100.0 \\
\hline 34 & & 100.0 & & 100.0 & & 87.2 & & 100.0 & & 100.0 & & 100.0 & & 100.0 \\
\hline 35 & & 100.0 & & 100.0 & & 65.9 & & 100.0 & & 100.0 & & 99.7 & & 100.0 \\
\hline 36 & & 100.0 & & 100.0 & TL & 50.4 & & 100.0 & & 99.8 & & 91.1 & & 100.0 \\
\hline 37 & & 100.0 & & 100.0 & TL & 35.6 & & 100.0 & & 92.0 & & 72.3 & & 99.9 \\
\hline 38 & & 98.8 & & 100.0 & TL & 17.4 & & 91.7 & & 74.5 & & 55.0 & & 93.2 \\
\hline 39 & & 87.7 & & 100.0 & TL & 5.7 & & 76.4 & & 56.8 & TL & 41.7 & & 75.9 \\
\hline 40 & & 67.3 & & 98.2 & TL & 0.3 & & 54.3 & TL & 43.4 & $\mathrm{TL}$ & 25.1 & & 57.7 \\
\hline 41 & & 51.9 & & 87.2 & TL & & & 36.8 & TL & 27.6 & TL & 9.5 & TL & 41.7 \\
\hline 42 & TL & 37.7 & & 67.1 & TL & & TL & 10.9 & TL & 10.9 & TL & 1.8 & TL & 24.6 \\
\hline 43 & $\mathrm{TL}$ & 22.6 & & 51.7 & $\mathrm{TL}$ & & TL lvisc & & $\mathrm{TL}$ & 3.3 & $\mathrm{TL}$ & & $\mathrm{TL}$ & 7.4 \\
\hline 44 & $\mathrm{TL}$ & 8.3 & TL & 17.6 & TL & & TL lvisc Neph & & TL & & $\mathrm{TL}$ & & $\mathrm{TL}$ & 0.3 \\
\hline 45 & $\mathrm{TL}$ & 0.9 & $\mathrm{TL}$ & 6.0 & $\mathrm{TL}$ & & TL lvisc Neph & & $\mathrm{TL}$ & & $\mathrm{TL}$ & & TL Neph & \\
\hline 46 & TL & & TL Neph & & TL & & TL lvisc Neph & & TL Neph & & $\mathrm{TL}$ & & TL Neph & \\
\hline 47 & $\mathrm{TL}$ & & TL Neph & & $\mathrm{TL}$ & & TL lvisc Neph & & TL Neph & & $\mathrm{TL}$ & & TL lvisc Neph & \\
\hline 48 & TL Neph & & TL Neph & & $\mathrm{TL}$ & & TL lvisc Neph & & TL Neph & & TL Neph & & TL lvisc Neph & \\
\hline 49 & TL Neph & & TL Neph & & TL & & TL lvisc Neph & & TL Neph & & TL Neph & & TL lvisc Neph & \\
\hline 50 & TL Neph & & TL Neph & & TL Neph & & TL lvisc Neph & & TL lvisc Neph & & TL Neph & & TL lvisc Neph & \\
\hline 51 & TL Neph & & TL Neph & & TL Neph & & TL lvisc Neph & & TL lvisc Neph & & TL Neph & & TL lvisc Neph & \\
\hline 52 & TL Neph & & TL Neph & & TL Neph & & TL lvisc Neph & & TL lvisc Neph & & TL Neph & & TL lvisc Neph & \\
\hline 53 & TL Neph & & TL lvisc Neph & & TL Neph & & TL lvisc Neph & & TL lvisc Neph & & TL lvisc Neph & & TL lvisc Neph & \\
\hline 54 & TL Neph & & TL lvisc Neph & & TL Neph & & TL lvisc Neph & & TL lvisc Neph & & TL lvisc Neph & & TL lvisc Neph & \\
\hline 55 & TL Neph & & TL lvisc Neph & & TL Neph & & TL lvisc Neph & & TL lvisc Neph & & TL lvisc Neph & & TL lvisc Neph & \\
\hline 56 & TL Neph & & TL lvisc Neph & & TL Neph & & TL lvisc Neph & & TL lvisc Neph & & TL lvisc Neph & & TL lvisc Neph & \\
\hline 57 & TL Neph & & TL lvisc Neph & & TL Neph & & TL lvisc Neph & & TL lvisc Neph & & TL lvisc Neph & & TL lvisc Neph & \\
\hline 58 & TL lvisc Neph & & TL lvisc Neph & & TL lvisc Neph & & TL lvisc Neph & & TL lvisc Neph & & TL lvisc Neph & & TL lvisc Neph & \\
\hline 59 & TL lvisc Neph & & TL lvisc Neph & & TL lvisc Neph & & TL lvisc Neph & & TL lvisc Neph & & TL lvisc Neph & & TL lvisc Neph & \\
\hline 60 & TL lvisc Neph & & TL lvisc Neph & & TL lvisc Neph & & TL lvisc Neph & & TL lvisc Neph & & TL lvisc Neph & & TL lvisc Neph & \\
\hline
\end{tabular}




\section{Distribution:}

J.E. Marra, 773-A

R.E. Edwards, 773-A

M.K. Harris, 773-42A

N.C. Iyer, 773-41A

D.A. Crowley, 999-W

T.B. Calloway, 999-W

C.C. Herman, 773-42A

D.B. Burns, 786-5A

G.T. Chandler, 773-A

N.E. Bibler, 773-A

C.M. Jantzen, 773-A

J.R. Harbour, 773-42A

R.C. Tuckfield, 773-42A

D.K. Peeler, 999-W

T.B. Edwards, 999-W

K.M. Fox, 773-A
T.M. Jones, 999-W

A.S. Choi, 999-W

M.E. Smith, 773-42A

M.E. Stone, 999-W

D.H. Miller, 999-W

S.D. Burke, 704-S

J.E. Occhipinti, 704-S

A.V. Staub, 704-27S

R.T. McNew, 704-27S

B.A. Davis, 704-27S

B.H. Culbertson, 704-27S

J.F. Iaukea, 704-30S

J.W. Ray, 704-S

C.G. Lampley 703-H

J.M. Gillam 766-H

H.B. Shah, 766-H 